This document was prepared in conjunction with work accomplished under Contract No. DE-AC09-96SR18500 with the U. S. Department of Energy.

\title{
DISCLAIMER
}

This report was prepared as an account of work sponsored by an agency of the United States Government. Neither the United States Government nor any agency thereof, nor any of their employees, nor any of their contractors, subcontractors or their employees, makes any warranty, express or implied, or assumes any legal liability or responsibility for the accuracy, completeness, or any third party's use or the results of such use of any information, apparatus, product, or process disclosed, or represents that its use would not infringe privately owned rights. Reference herein to any specific commercial product, process, or service by trade name, trademark, manufacturer, or otherwise, does not necessarily constitute or imply its endorsement, recommendation, or favoring by the United States Government or any agency thereof or its contractors or subcontractors. The views and opinions of authors expressed herein do not necessarily state or reflect those of the United States Government or any agency thereof. 


\section{Vadose Zone VOC Mass Transfer Testing at the SRS Miscellaneous Chemical Basin}

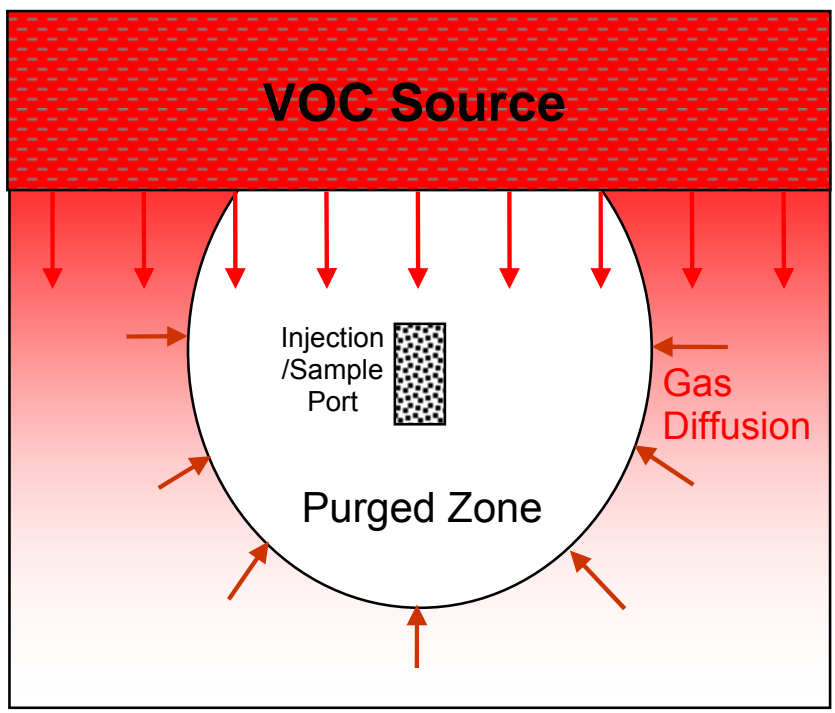

October 2005

Westinghouse Savannah River Company, LLC Savannah River Site Aiken, SC, 29808 


\section{Contents}

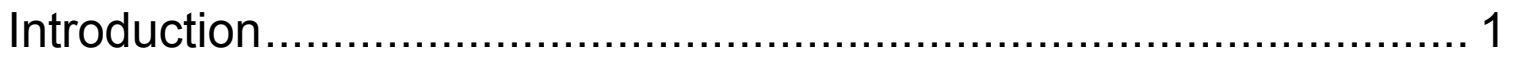

Background

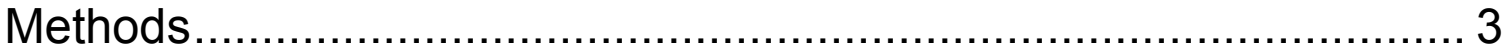

Soil Sample Collection for VOC Analysis ................................................

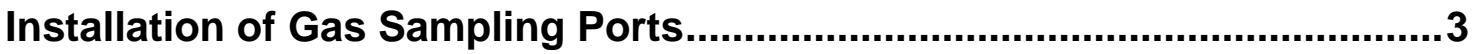

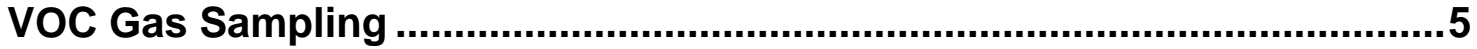

Headspace Analysis for VOCs in Soil ....................................................

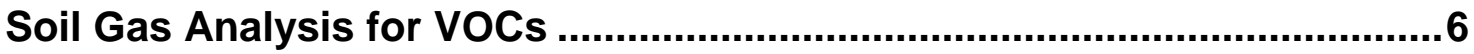

Protocol for Measurement of Mass Transfer Factors ................................... 7

2004 Monitoring and Characterization Analysis Results ................. 8

Field Mass Transfer Testing Theory and Application ................... 11

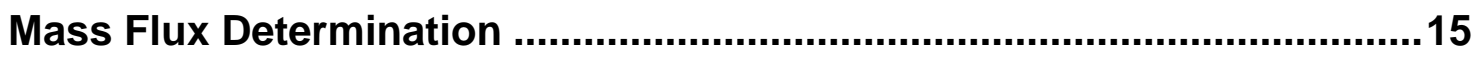

Summary and Conclusions...................................................... 19

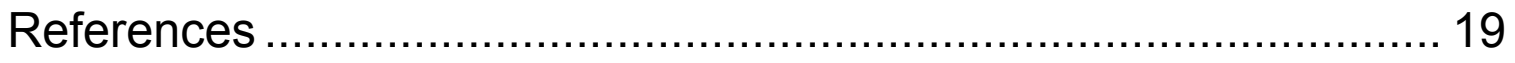

Appendix A - Sediment Analysis Results.................................. 20

Appendix B - Geophysical Parameters ......................................... 34

Appendix C - Integration Results for Total Mass Flux ................... 36 


\section{List of Tables}

Table 1 - Construction Details for MCBMT Injection/Sample Ports .....................5

Table 2 - Detection and Quantitation Limits for SRNL VOC Analysis..................7

Table 3 - VOC Gas Concentration from MCBMT Gas Sampling Ports on 4/12/04

Table 4 - Summary of Diffusion Coefficients Due to Mass Transfer $\left(D_{m t}\right) \ldots \ldots \ldots 15$

Table 5 - Flux Calculation Results for TCE ……...................................... 16

Table 6 - Flux Calculation Results for PCE ................................................. 16

Table 7 - Comparison of Diffusive Mass Flux and PSVE Removal ...................17

Table 8 - Sediment VOC Concentration $(\mathrm{mg} / \mathrm{kg})$ from Installation of MCBMT Injection/Sample Ports ............................................................20

Table 9 - Laboratory Measured Geophysical Parameters ................................34

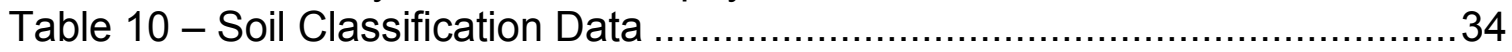

Table 11 - Water Retention Test Data......................................................

\section{List of Figures}

Figure 1 - Typical Injection/Sample Port Installation Diagram .......................... 4

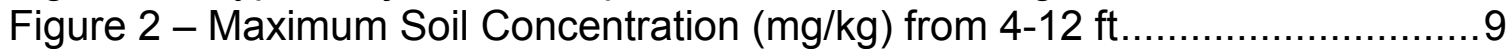

Figure 3 - Initial MCBMT Gas Concentration (ppmv) ..................................10

Figure 4 - Conceptual Model of VOC Concentration Increase after Purging Gas

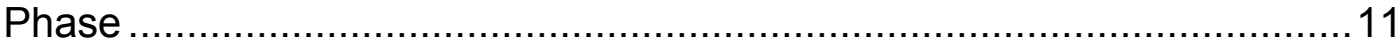

Figure 5 - Measured and Theoretical Concentration Response after Injection of

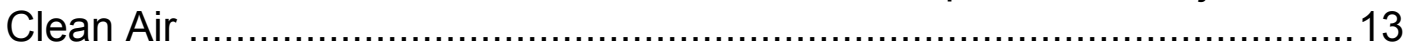

Figure 6 - Normalized PCE Field Concentration Data ....................................... 14

Figure 7 - Normalized TCE Field Concentration Data .................................... 14

Figure 8 - Mass Flux (filled) and Mass Transfer Diffusion Coefficient Contours in

$\mathrm{cm}^{2} / \mathrm{s}$ (not filled)............................................................................. 18

Figure 9 - Temporal Sediment Concentration at Location 1 ..........................24

Figure 10 - PCE Temporal Sediment Concentration at Location 1 ...................25

Figure 11 - TCE Temporal Sediment Concentration at Location 2 ....................26

Figure 12 - PCE Temporal Sediment Concentration at Location 2 ...................27

Figure 13 - TCE Temporal Sediment Concentration at Location 3...................28

Figure 14 - PCE Temporal Sediment Concentration at Location 3 ..................29

Figure 15 - PCE and TCE Temporal Sediment Concentration at Location 6 .....30

Figure 16 - TCE and PCE Sediment Concentration at MCBMT 5 and 6 ............31

Figure 17 - TCE and PCE Sediment Concentration at MCBMT 7 and 8 ............32

Figure 18 - TCE and PCE Sediment Concentration at MCBMT 9 ....................33 


\section{Introduction}

Active remedial activities have been ongoing since 1996 to address low levels of solvent contamination at the Miscellaneous Chemical Basin at SRS.

Contaminant levels in the subsurface may be approaching levels where mass transfer limitations are impacting the efficiency of the remedial action. Rate limited mass transfer effects have been observed at other sites in the vadose zone at the SRS, however, detailed measurements and evaluation has not been undertaken. Anecdotal evidence suggests that the mass transfer rates are very slow from the fine grain sediments. This conclusion is based on the observation that measured soil gas concentrations tend to be low in permeable zones relative to the higher concentrations found in fine grain zones.. Decreasing soil gas concentration with depth below the 'upland unit' at several areas at SRS is also evidence of slow diffusion rates.

In addition, due to the length of time since disposal ceased at the MCB, we hypothesize that mobile solvents have migrated downward, and the solvent remaining in the upper fine grain zone ('upland unit') are trapped in fine grain material and are primarily released by gas diffusion (Riha and Rossabi 2004). Natural weathering and other chemical solutions disposed with the solvents can further enhance this effect by increasing the micro-porosity in the clays (kaolinite). This microporosity can result in increased entrapment of water and solvents by capillary forces (Powers, et. al., 2003). Also supporting this conclusion is the observation that active SVE has proven ineffective on VOC removal from the fine grain zones at the SRS. Adsorption and the very slow release phenomenon have been documented similarly in the literature especially for old solvent spills such as at the SRS (Pavlostathis and Mathavan 1992; Oostrom and Lenhard 2003).

Mass transfer relationships need to be developed in order to optimize remediation activities and to determine actual loading rates to groundwater. These metrics will aid in answering the question 'How clean is protective of the environment'?

For this study, a field test was developed to measure a mass transfer factor by injecting clean air into the subsurface through a sample port or well and measuring the rebound VOC concentration over time. Interpretation of the he results of these tests will provide a mass transfer rate that will be used to determine the appropriate type of SVE for the area (passive, enhanced or active SVE), a measured field parameter to estimate mass loading to the groundwater, and time frame for cleanup.

\section{Background}

From evaluations of soil vapor extraction (SVE) systems at the Savannah River Site (SRS) and other sites, low VOC mass transfer in the vadose zone is one of the main limitations of active SVE. This scope is to refine a test to measure a field mass transfer factor to aid in optimizing the correct form of SVE specific to 
remediation in the sediments at SRS. The test is based on the USEPA respiration test for bioventing and entails displacing soil gas with a clean volume of air and measuring the concentration rebound over time. This test is designed to evaluate the diffusion from the vadose zone source areas. Field measurements from the initial testing of barometric pumping in the early $1990 \mathrm{~s}$ show a concentration rebound after surface air influx. Based on the theory and field observations, the author believes this innovative approach provides a realistic rate of mass transfer in the vadose zone. This testing would be beneficial at multiple remedial sites at SRS.

The Miscellaneous Chemical Basin (MCB) waste unit is located in the northwest portion of SRS, approximately 1.5 miles south of the $3 / 700$ Area operations and 3 miles east of the SRS boundary. Little information is available on the historical operations of the basin. It is thought to have received liquid wastes from the $3 / 700$ Area operations, consisting primarily of waste solvent and used oil. It is also believed that partially full drums were emptied at this site.

The historical boundaries of the basin have been estimated based on site photographs. The MCB was approximately 20 by 20 feet in length and width, and approximately 1 foot deep. Photographs indicate that the basin received liquid chemical wastes from about 1956 to 1974 and was located in a shallow borrow pit covering a small portion of the waste unit. In 1974, the basin was re-graded and the original near-surface basin sediments were distributed in a field at the site with approximate dimensions of 350 by 350 feet. In 2001, the surface soils were removed and replaced with clean fill. Weeds and grass currently cover the site. The surface of the waste unit exhibits a slight slope of approximately 3 percent to the east-southeast. The center of the soil gas plume does not correspond to the original basin location and little evidence of oil or hydrocarbon contamination is found.

The MCB is a Resource Conservation and Recovery Act (RCRA) solid waste management unit and a Comprehensive Environmental Response, Compensation, and Liability Act (CERCLA) waste unit. It is currently undergoing remediation as stated in the approved Interim Record of Decision Remedial Alternatives Selection for the Miscellaneous Chemical Basin/Metals Burning Pit (731-4A/5A) Operable Unit (WSRC-RP-98-4031) and the Interim Corrective Measures Implementation/Interim Remedial Action Implementation Plan for the Miscellaneous Chemical Basin/Metals Burning Pit (731-4A/5A) (WSRC-RP-994037).

Earlier characterization conducted at the MCB includes collection of continuous geologic profiles, soil gas surveys, soil samples, and groundwater monitoring samples. During September and October of 1996, 27 cone penetrometer test (CPT) pushes were completed to characterize the site. The results include continuous litholoigic soil gas profiles. Vadose zone wells were installed at each location for passive remediation. Soil samples were collected and analyzed for 
WSRC-TR-2005-00266

MCB Mass Transfer Testing [Page 3]

VOCs in 1996, 1997, 2001, and 2003 in order to monitor the progress of remediation.

Passive soil vapor extraction (PSVE) was initiated in September 1996 following the installation of the wells. Active soil vapor extraction was initiated in October 2001 and was terminated in December 2002. The MCB is currently under the final polishing step of remediation using PSVE. Sediment and soil gas concentrations have decreased significantly during the remediation efforts.

\section{Methods}

\section{Soil Sample Collection for VOC Analysis}

Soil samples were collected at 9 locations at the MCB to support this study. Continuous samples were collected in one foot increments from a depth of approximately $4 \mathrm{ft}$ to a maximum depth of $12 \mathrm{ft}$ at each location. The sampling depths targeted the 'upland unit' identified during the characterization campaign completed in 1996 (Riha et al. 1996). The presence of the 'upland sediments' were confirmed by visual inspection of the soil core. The goal was to sample to just below the 'upland unit' and then to install the injection/sample ports to interrogate the source area.

Soil samples were collected using direct push wireline sampling equipment. The wireline sampling tool uses 2.25 -inch diameter rods with a removable dummy push tip and core barrel with a locking mechanism that fits inside the push rods. The wireline tool allows the recovery of multiple soil samples without removing and reinserting the push rod string significantly reducing the amount of time required to collect soil samples.

When the core was brought to the surface, a 2 cubic centimeter (cc) soil plug was collected using a modified plastic syringe. The plug was immediately transferred to a $22 \mathrm{ml}$ glass headspace vial with $5 \mathrm{ml}$ of nano-pure water. The vial was then sealed with a crimped Teflon-lined septum top for head-space analysis. Duplicate samples were collected at each depth.

\section{Installation of Gas Sampling Ports}

Gas sampling ports were installed in the open borehole after soil sampling was completed. The sampling ports are constructed of a 6 -inch long by 0.5 -inch diameter sintered stainless steel tube with Swagelok ${ }^{\mathrm{TM}}$ stainless steel fittings. Approximately $0.5 \mathrm{ft}$ of filter sand was placed in the bottom the hole. The ports were connected to 0.25 inch diameter polyethylene tubing and lowered into the borehole. Sand was added to create a 1 foot thick sand filter pack followed by 1 foot of dry bentonite crumbles to seal the borehole above the sand pack. The bentonite was hydrated for a minimum of 1 hour before grouting the borehole to the surface. Depths and heights of fill material were verified using a metered tag line with an accuracy of $0.1 \mathrm{ft}$ from the ground surface. The sampling ports were 
WSRC-TR-2005-00266

MCB Mass Transfer Testing [Page 4]

finished with a Swagelok cap and surface cover. A typical installation diagram is shown in Figure 1 and the construction details are provided in Table 1.

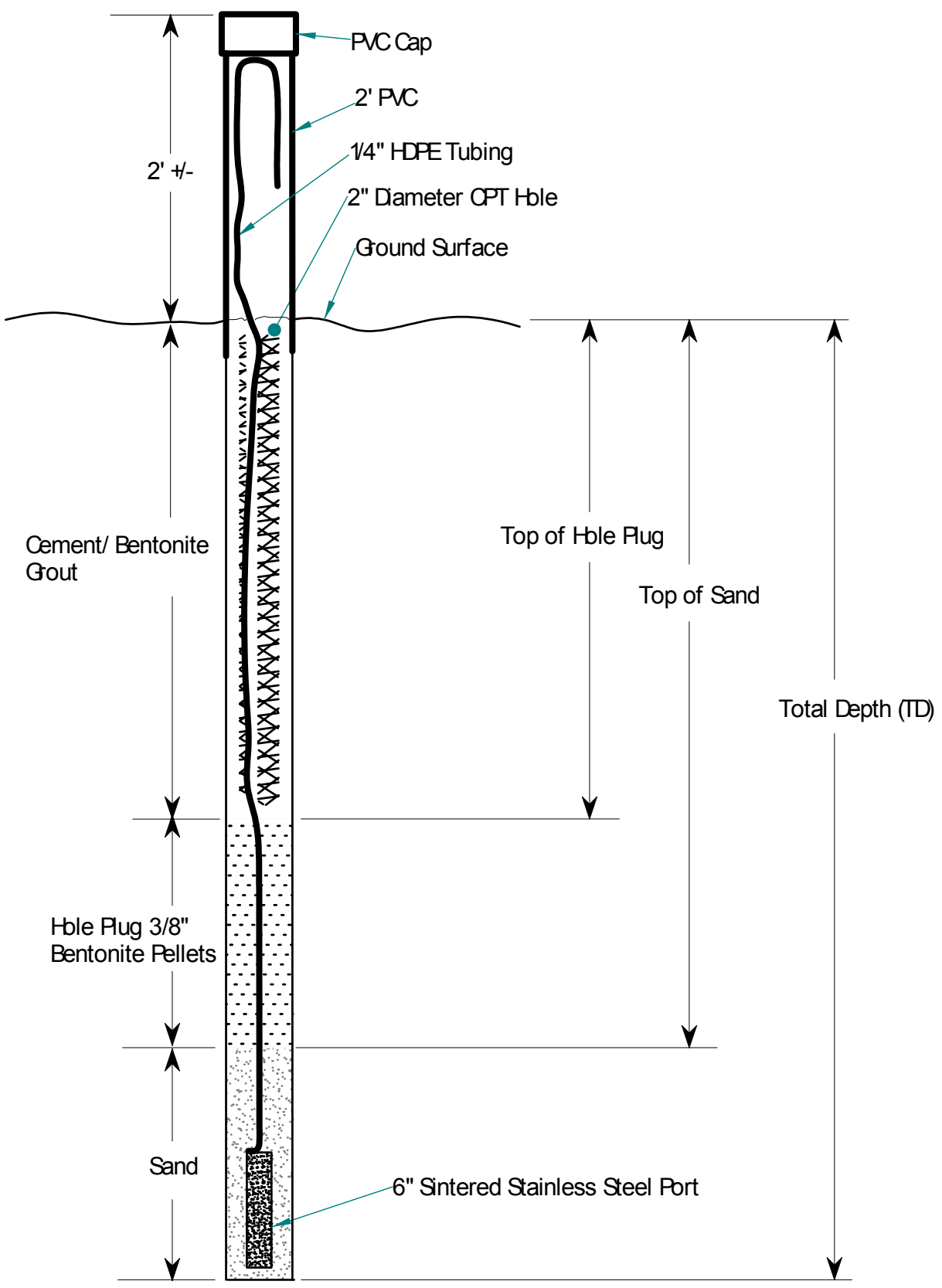

Figure 1 - Typical Injection/Sample Port Installation Diagram 
Table 1 - Construction Details for MCBMT Injection/Sample Ports

\begin{tabular}{|c|c|c|c|c|c|c|c|c|}
\hline Well ID & $\begin{array}{c}\text { Total } \\
\text { Depth (ft) }\end{array}$ & $\begin{array}{c}\text { Top of } \\
\text { Sand (ft) }\end{array}$ & $\begin{array}{c}\text { Top of } \\
\text { Hole Plug } \\
(\mathrm{ft})\end{array}$ & $\begin{array}{c}\text { Thickness } \\
\text { of Sand } \\
\text { Layer }(\mathrm{ft})\end{array}$ & $\begin{array}{c}\text { Thickness } \\
\text { of Hole } \\
\text { Plug } \\
\text { Layer (ft) }\end{array}$ & Northing & Easting & $\begin{array}{c}\text { Surface } \\
\text { Elevation } \\
(\mathrm{ft} \mathrm{msl})\end{array}$ \\
\hline MCBMT-1 & 9.8 & 8.8 & 7.8 & 1.0 & 1.0 & 97325.07 & 44876.55 & 337.0 \\
\hline MCBMT-2 & 11.9 & 10.0 & 9.0 & 1.9 & 1.0 & 97394.43 & 44863.85 & 338.7 \\
\hline MCBMT-3 & 9.8 & 8.6 & 7.7 & 1.2 & 0.9 & 97337.03 & 44903.83 & 336.6 \\
\hline MCBMT-4 & 9.7 & 8.5 & 7.6 & 1.2 & 0.9 & 97364.92 & 44866.66 & 338.2 \\
\hline MCBMT-5 & 10.0 & 9.0 & 8.0 & 1.0 & 1.0 & 97380.74 & 44825.61 & 339.2 \\
\hline MCBMT-6 & 8.7 & 7.7 & 6.6 & 1.0 & 1.1 & 97327.01 & 44819.64 & 338.2 \\
\hline MCBMT-7 & 9.8 & 8.8 & 7.8 & 1.0 & 1.0 & 97290.83 & 44873.60 & 336.3 \\
\hline MCBMT-8 & 8.9 & 7.9 & 6.8 & 1.0 & 1.1 & 97351.05 & 44835.00 & 338.5 \\
\hline MCBMT-9 & 12.0 & 11.0 & 10.0 & 1.0 & 1.0 & 97290.07 & 44841.93 & 337.2 \\
\hline
\end{tabular}

\section{VOC Gas Sampling}

Initial VOC concentrations were measured in the field from soil gas drawn from the sample ports. The sampling method used a dual head Teflon and stainless steel pump to collect vapor for analysis with an Innova Model 1312 infra-red photo-acoustic spectrometer (IRPAS) capable of differentiating PCE, TCE and carbon dioxide $\left(\mathrm{CO}_{2}\right)$.

Initially, sample points were purged until $\mathrm{CO}_{2}$ levels were stable. After purging PCE, TCE, and $\mathrm{CO}_{2}$ field data were recorded. Stability was usually reached within minutes due to the short screen zones.

Additional soil gas samples were collected in $22 \mathrm{ml}$ glass vials for gas chromatography screening analysis at SRNL. A vial and Teflon lined septum crimp top were placed in a thin wall, ziplock polyethylene bag (sandwich bag). The vial and bag were purged with soil gas from the sampling pump and the bag was sealed. The vial was then sealed through the bag by crimping the top. The vials were analyzed at SRNL within 7 days.

\section{Headspace Analysis for VOCs in Soil}

The technique used to prepare and analyze sediment samples for VOC analysis is a modified version of EPA Method 5021 which has been used successfully at the SRS since 1991. Each sample is weighed and then analyzed on the HP 5890 Series II or HP 6890 gas chromatograph (GC) using an automated head space sampler at $70^{\circ} \mathrm{C}$ for equivalent water concentrations. The GC is equipped with an electron capture and flame ionization detector connected in parallel. The column is a Supelco - VOCOL ${ }^{\mathrm{TM}}$ megabore borosilicate glass $(60 \mathrm{~m} \times 0.76 \mathrm{~mm}$ ID $\times 1.5 \mu \mathrm{m}$ film thickness) specifically developed for volatile priority pollutants (EPA Methods 502, 602, and 8240). Mass soil concentrations (ppmm, $\mathrm{mg} / \mathrm{kg}$ ) are calculated based on an equal head space volume from $7.5 \mathrm{ml}$ of water standards and nominal $7 \mathrm{ml}$ of water/soil matrix, and are corrected for the mass difference between the soil and water. The gas chromatograph is calibrated 
WSRC-TR-2005-00266

MCB Mass Transfer Testing [Page 6]

using purchased certified mixtures in methanol that are diluted in deionized water to specific concentrations. Two reagent blanks of pure deionized water are included after the high concentration standards to ensure the transfer lines and column are being adequately flushed of residual solvents. The standard concentrations used for each head space sample run are: $3,5,10,50,100$, 1,000 , and $10,000 \mathrm{ppb}(\mu \mathrm{g} / \mathrm{l})$. A selected suite of compounds are used based on the primary contaminants expected at DOE sites. The samples were analyzed for 1,1-dichloroethylene (1,1-DCE), carbon tetrachloride $\left(\mathrm{CCl}_{4}\right)$, cis-1,2dichloroethylene (cis-DCE), trichlorofluoromethane (Freon 11), chloroform, Freon 113, perchloroethylene (PCE), 1,1,1-trichloroethane (TCA), trichloroethylene (TCE), trans-1,2-dichloroethylene (trans-DCE), and toluene. The minimum detection limit (MDL) and minimum quantitation limit (MQL) for soil and water analysis are provided in Table 2.

\section{Soil Gas Analysis for VOCs}

For soil gas samples, the same GC and autosampler systems were used for analysis. Gas standards were prepared similarly to the gas sampling method described above using certified gas standards at nominal 1, 10, and $100 \mathrm{ppmv}$ concentrations. The gas samples were analyzed for benzene, carbon tetrachloride $\left(\mathrm{CCl}_{4}\right)$, cis-1,2-dichloroethylene (cis-DCE), trichlorofluoromethane (Freon 11), chloroform, Freon 113, methylene chloride (MECL), perchloroethylene (PCE), 1,1,1-trichloroethane (TCA), trichloroethylene (TCE), trans-1,2-dichloroethylene (trans-DCE), and toluene. The minimum detection limit (MDL) and minimum quantitation limit (MQL) for soil gas analysis is provided in Table 2.

The data reported from these analyses are considered screening level data. Although standard laboratory methods are followed, the laboratory is not certified by any federal or state agency for analyses required for specific permit analysis requirements. All reported data should be accompanied with this flag. 
Table 2 - Detection and Quantitation Limits for SRNL VOC Analysis

\begin{tabular}{|c|c|c|c|c|c|}
\hline & & Soil An & nalysis & Gas An & nalysis \\
\hline $\begin{array}{l}\text { SRNL } \\
\text { Name }\end{array}$ & Compound & MDL $\mu \mathrm{g} / \mathrm{kg} \|$ & MQL $\mu \mathrm{g} / \mathrm{kg}$ & MDL, ppmvI & vMQL, ppmv \\
\hline 11DCE & $1,1 \mathrm{DCE}$ & 0.365 & 4.5 & na & a $\quad$ na \\
\hline BENZ & Benzene & 1.920 & 4.5 & 0.2 & 0. \\
\hline CCL4 & carbon tet & 0.006 & 4.5 & 0.0005 & 0.001 \\
\hline C-DCE & cis-DCE & 5.284 & 8.3 & 0.4 & 0.6 \\
\hline CFC11 & Freon-11 & 0.004 & 4.5 & 0.0005 & 0.001 \\
\hline CHCL3 & Chloroform & 0.078 & 4.5 & 0.005 & 0.009 \\
\hline FR113 & Freon-113 & 0.030 & 4.5 & 0.003 & 0.01 \\
\hline MECL & dichloromethane & 3.917 & 4.5 & 0.4 & 0.7 \\
\hline PCE & PCE & 0.011 & 4.5 & 0.0006 & 0.001 \\
\hline TCA & TCA & 0.023 & 4.5 & 0.002 & 0.003 \\
\hline TCE & TCE & 0.050 & 4.5 & 0.004 & 0.006 \\
\hline T-DCE & trans-DCE & 3.812 & 4.5 & 0.4 & 0.7 \\
\hline TOL & Toluene & 1.965 & 4.5 & 0.1 & 0.2 \\
\hline
\end{tabular}

\section{Protocol for Measurement of Mass Transfer Factors}

The field measurement of the mass transfer factors consisted of the following three steps:

1. Measurement of the initial gas concentration from injection/sample port.

A dual head Teflon and stainless steel pump was used to collect vapor for analysis with an Innova Model 1312 infra-red photo-acoustic spectrometer (IRPAS) capable of differentiating PCE, TCE and carbon dioxide $\left(\mathrm{CO}_{2}\right)$. Gas vials for $G C$ analyses were also collected as described above. The IRPAS instrument was used as a quick quality check in the field and to measure $\mathrm{CO}_{2}$ as a psuedo tracer. The quality check consisted of monitoring the expected concentration trends during the test (i.e. low initial concentrations and increasing concentrations with time)

2. Injection of clean air into the vadose zone around the sampling point to displace the VOC gas phase.

Laboratory grade air (79\% nitrogen, $21 \%$ oxygen and $0 \% \mathrm{CO}_{2}-$ Air Liquide Alphagaz 1) from a pressurized cylinder was injected into the subsurface through the injection/monitoring points. A $25 \mathrm{ft}^{3}$ air injection volume was used to create a purged sphere of approximately $125 \mathrm{~cm}$ radius using an estimated air filled porosity $\left(\theta_{a}\right)$ of 0.17 . An Omega Model FL-2008 rotometer was used to meter the air at 50 scfh for 30 minutes. Injection pressure was also monitored. 
3. Collection of gas samples over time while minimizing sample volume to avoid advective movement of VOC gas phase from surrounding sediments.

Immediately after the injection was stopped, low-flow, low-volume gas samples were collected from the sample port using the sampling system described above. A sample was collected immediately after injection, then every 10 minutes for the first hour, then every 30 minutes for the second hour and then hourly up to 7 hours. Samples from several of the sample locations were collected at later times to evaluate the rebound to the starting concentration. A one liter Tedlar bag was filled for the IRPAS analysis and a gas vial was filled for GC analysis during each sampling event. Less than 4 liters of gas was removed during each sampling event. A maximum of 52 liters $\left(1.8 \mathrm{ft}^{3}\right)$ would have been removed during each test (less than $10 \%$ of the total injection volume).

\section{Monitoring and Characterization Analysis Results}

\section{Sediment/Soil Analysis}

Continuous sediment samples were collected for VOC analysis during installation of the gas ports for this study. Results for VOCs ranged from non-detect to 7.22 $\mathrm{mg} / \mathrm{kg} \mathrm{PCE}, 24.70 \mathrm{mg} / \mathrm{kg}$ TCE, $0.15 \mathrm{mg} / \mathrm{kg} \mathrm{CCl} 4,1.15 \mathrm{mg} / \mathrm{kg}$ Freon 11 and 0.16 $\mathrm{mg} / \mathrm{kg}$ trans-DCE. Soil concentrations decreased with depth. Analysis results are tabulated in Appendix A and are provided graphically in context with cone penetrometer test (CPT) friction ratio logs and previous soil analysis results where available.

\section{Soil Gas Analysis}

Initial soil gas concentrations from the MCBMT ports measured with an IRPAS instrument is provided in Table 3 . Concentration contour plots showing the maximum soil and port gas concentrations are provided in Figure 2 and Figure 3, respectively.

Table 3 - VOC Gas Concentration from MCBMT Gas Sampling Ports on 4/12/04

\begin{tabular}{|l|r|r|r|r|l|r|r|}
\hline $\begin{array}{l}\text { Injection / } \\
\text { Sample Port } \\
\text { Location }\end{array}$ & Northing & Easting & $\begin{array}{l}\text { Surface } \\
\text { Elevation } \\
\mathrm{ft} \text { msl }\end{array}$ & $\begin{array}{l}\text { Bottom } \\
\text { Depth, } \mathrm{ft}\end{array}$ & $\begin{array}{l}\text { PCE } \\
\mathrm{ppmv}\end{array}$ & $\begin{array}{l}\text { TCE } \\
\mathrm{ppmv}\end{array}$ & $\begin{array}{l}\mathrm{CO}_{2} \\
\mathrm{ppmv}\end{array}$ \\
\hline MCBMT-1 & 97325.1 & 44876.6 & 337.0 & 9.8 & 3.6 & 14.8 & 11,100 \\
\hline MCBMT-2 & 97394.4 & 44863.9 & 338.7 & 11.9 & 4.3 & 5.8 & 1,580 \\
\hline MCBMT-3 & 97337.0 & 44903.8 & 336.6 & 9.8 & 0.7 & 1.2 & 10,100 \\
\hline MCBMT-4 & 97364.9 & 44866.7 & 338.2 & 9.7 & 45.1 & 133.0 & 16,800 \\
\hline MCBMT-5 & 97380.7 & 44825.6 & 339.2 & 10.0 & 62.6 & 12.0 & 11,900 \\
\hline MCBMT-6 & 97327.0 & 44819.6 & 338.2 & 8.7 & 5.1 & 2.6 & 12,400 \\
\hline MCBMT-7 & 97290.8 & 44873.6 & 336.3 & 9.8 & 6.8 & 536.0 & 16,300 \\
\hline MCBMT-8 & 97351.1 & 44835.0 & 338.5 & 8.9 & 66.4 & 159.0 & 22,800 \\
\hline MCBMT-9 & 97290.1 & 44841.9 & 337.2 & 12.0 & 1.7 & 4.3 & 12,800 \\
\hline
\end{tabular}

Measurements made by IRPAS 
WSRC-TR-2005-00266 MCB Mass Transfer Testing [Page 9]
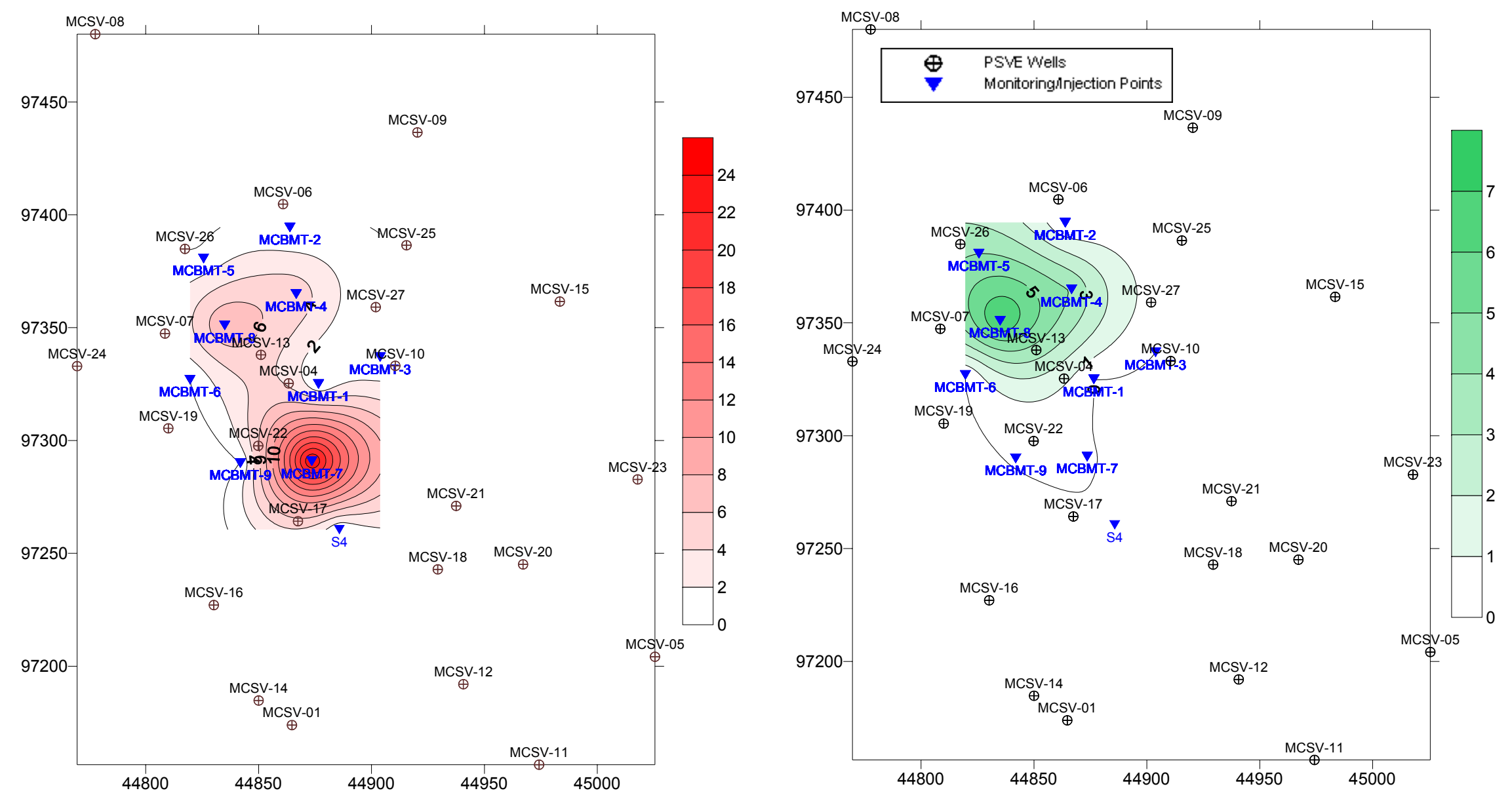

Figure 2 - Maximum Soil Concentration (mg/kg) from 4-12 ft 
WSRC-TR-2005-00266

MCB Mass Transfer Testing [Page 10]
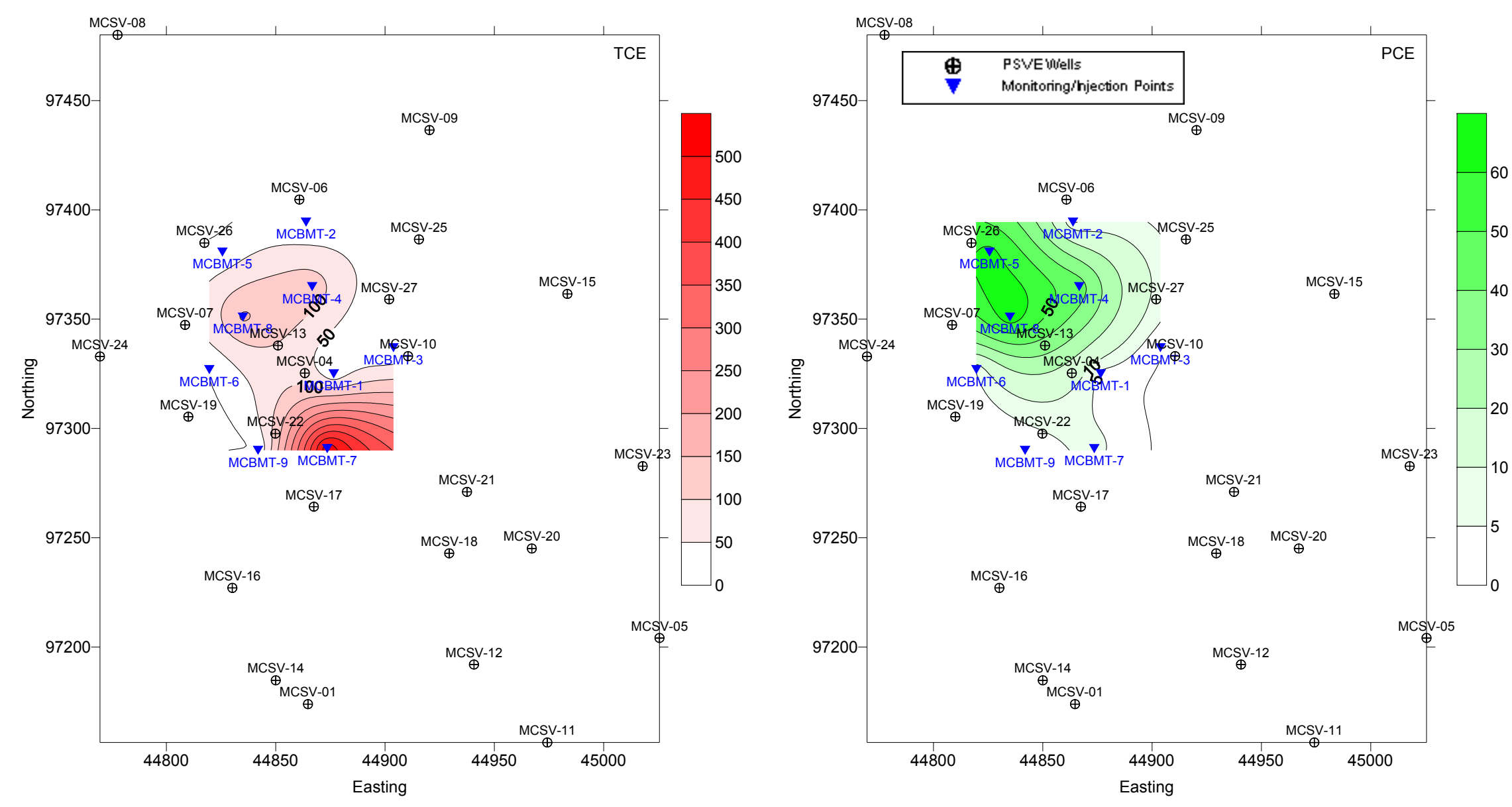

Figure 3 - Initial MCBMT Gas Concentration (ppmv) 


\section{Field Mass Transfer Testing Theory and Application}

In theory, the gas concentration measured during rebound after displacement of the soil gas by air is an integrated measurement of the combined mass transfer of VOCs from the sorbed and dissolved phases and by gas diffusion from fine grain zones. The current conceptual model for solvent transport in the vadose zone at the SRS is that it is dominated by vapor diffusion from trapped solvent in fine grain zones. This conceptual model was developed based on observation of time concentration trends of VOCs in the vadose zone as well as the long time period since solvent disposal ceased. Based on this conceptual model, it would be expected that after injecting a volume of clean air to purge the solvent gas phase in the surrounding sediments, that the initial concentration increase would be a direct measure of the release of solvents from the fine grain materials. A diagrammatic representation of this conceptual model showing the release of solvents from a fine grained source area into the purged zone is provided in Figure 4.

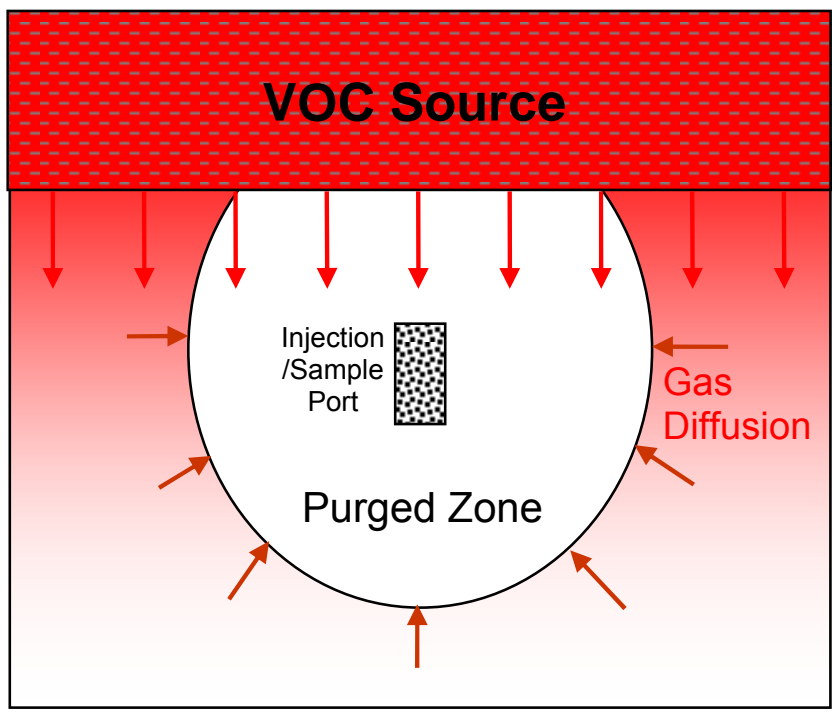

Figure 4 - Conceptual Model of VOC Concentration Increase after Purging Gas Phase

The release of solvent during diffusion can result from several distinct mechanisms including the following: diffusion from contaminated pore water to soil gas, mass transfer from fine grain source material to soil gas, and gas diffusion from outside the purged zone into the purged zone. Based on theoretical considerations, these different mechanisms would occur in the following sequence after injection:

$\left(t_{w}\right)$ rapid concentration increase due to pore water (water film) to gas diffusion,

$\left(t_{s}\right)$ increase in concentration due to mass transfer from the source in fine grain zones, and,

$\left(t_{d}\right)$ increase in concentration due to gas diffusion outside the purged zone. 
The increase from the water film on the soil grains should happen very rapidly $\left(t_{w}\right)$ assuming a stagnant two film model (water film to gas). The total diffusion times should be on the order of seconds (Schwarzenbach et al., 1993). The diffusion from outside the purged zone can be estimated using a spherical diffusion model modified to be consistent with flow through porous media (Crank, 1956; Johnson et al., 1998). Equation 1 is the analytical solution for diffusion in a sphere of finite radius $\left(R_{0}\right)$ and initial vapor concentration of $C_{V}{ }^{0} . R_{0}$ is corrected for the air filled porosity $\left(\theta_{a}\right)$ based on the total volume of clean air injected. The concentration data were normalized for calculation purposes.

$$
C_{v}(r, t)=C_{v}^{o}-\left(\begin{array}{l}
\frac{C_{v}^{o}}{2}\left\{\operatorname{erf}\left[\frac{R_{o}+r}{2 \sqrt{D t}}\right]+\operatorname{erf}\left[\left[\frac{R_{o}-r}{2 \sqrt{D t}}\right]\right]\right\}- \\
\left.\frac{C_{v}^{o}}{r} \sqrt{\frac{D t}{\pi}}\left\{\exp \left[-\frac{\left(R_{o}-r\right)^{2}}{4 D t}\right]-\exp \left[-\frac{\left(R_{o}+r\right)^{2}}{4 D t}\right]\right\}\right)
\end{array}\right) \text { Equation } 1
$$

where

$R_{0}=$ radius of sphere of clean air $(\mathrm{cm})$

$C_{V}(r, t)=$ vapor concentration at distance $r$ and time $t(\mathrm{ppmv})$

$C_{v}{ }^{0}=$ steady state vapor concentration (ppmv)

$D=$ effective diffusion coefficient $\left(\mathrm{cm}^{2} / \mathrm{s}\right)$

Measured values of field effective diffusion coefficients $(D)$ at a site with sandy silts and clayey silts ranged from 0.0007 to $0.087 \mathrm{~cm}^{2} / \mathrm{s}$. These values were used to bound the modeled values for diffusion back into the purged sphere.

These relationships were found in the measured data as illustrated in Figure 5. Figure 5 shows the normalized PCE concentration data (PCE $C / C_{0}$ ) measured at port MCBMT-4 using a $25 \mathrm{ft}^{3}$ air injection volume and estimated air filled porosity $\left(\theta_{\mathrm{a}}\right)$ of 0.17 . 


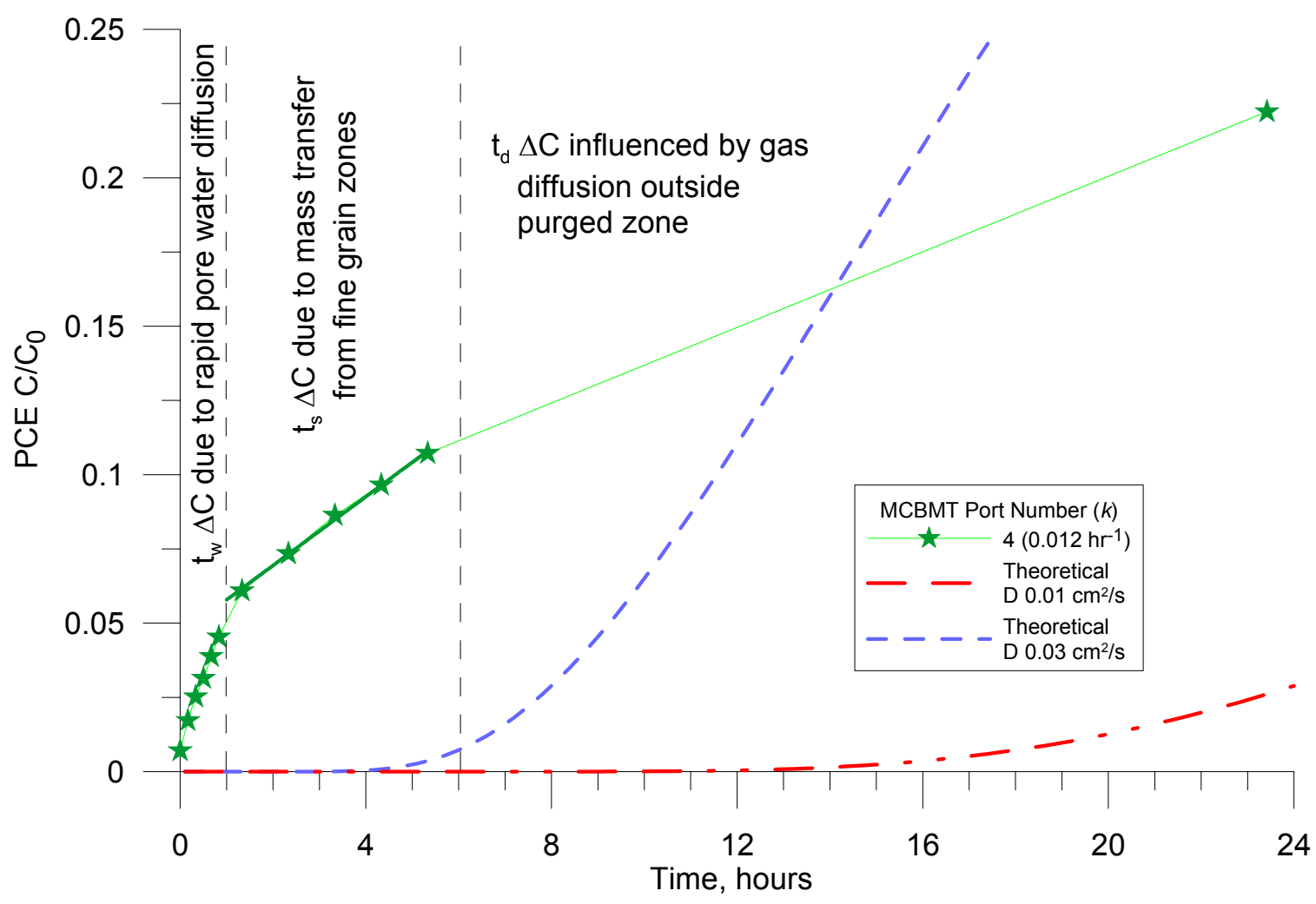

Figure 5 - Measured and Theoretical Concentration Response after Injection of Clean Air

Based on the diffusion calculations from Equation 1 and the field test concentration trends, the following time periods were defined to determine a mass transfer diffusion coefficient $\left(D_{m t}\right)$ during $t_{s}$.

$\mathrm{t}_{\mathrm{w}}: \quad \Delta \mathrm{C}$ due to rapid pore water diffusion $(<1 \mathrm{hr})$

$\mathrm{t}_{\mathrm{s}}$ : $\quad \Delta \mathrm{C}$ due to mass transfer from fine grain zones (1 to $6 \mathrm{hr}$ )

$\mathrm{t}_{\mathrm{d}}$ : $\quad \Delta \mathrm{C}$ influenced by gas diffusion from outside the purged zone $(>6$ hr)

The normalized concentration trends were linearly fit using the field concentration data from 1 to 6 hrs after injection. The concentration data from all the ports at the MCB fit the time trends and are expected to be similar for other source areas in the 'upland unit' at the SRS. The normalized data and fitted lines from the 8 tested ports are shown in Figure 6 and Figure 7. Assuming a unit area of $1 \mathrm{~m}^{2}$ and concentration measurements in $\mathrm{mg} / \mathrm{m}^{3}$, the $D_{m t}$ provides a measure of the field mass transfer coefficient from the fine grain zones. $D_{m t}$, converted to $\mathrm{cm}^{2} / \mathrm{s}$, linear regression coefficients and initial concentrations are tabulated in Table 4. 
WSRC-TR-2005-00266

MCB Mass Transfer Testing [Page 14]

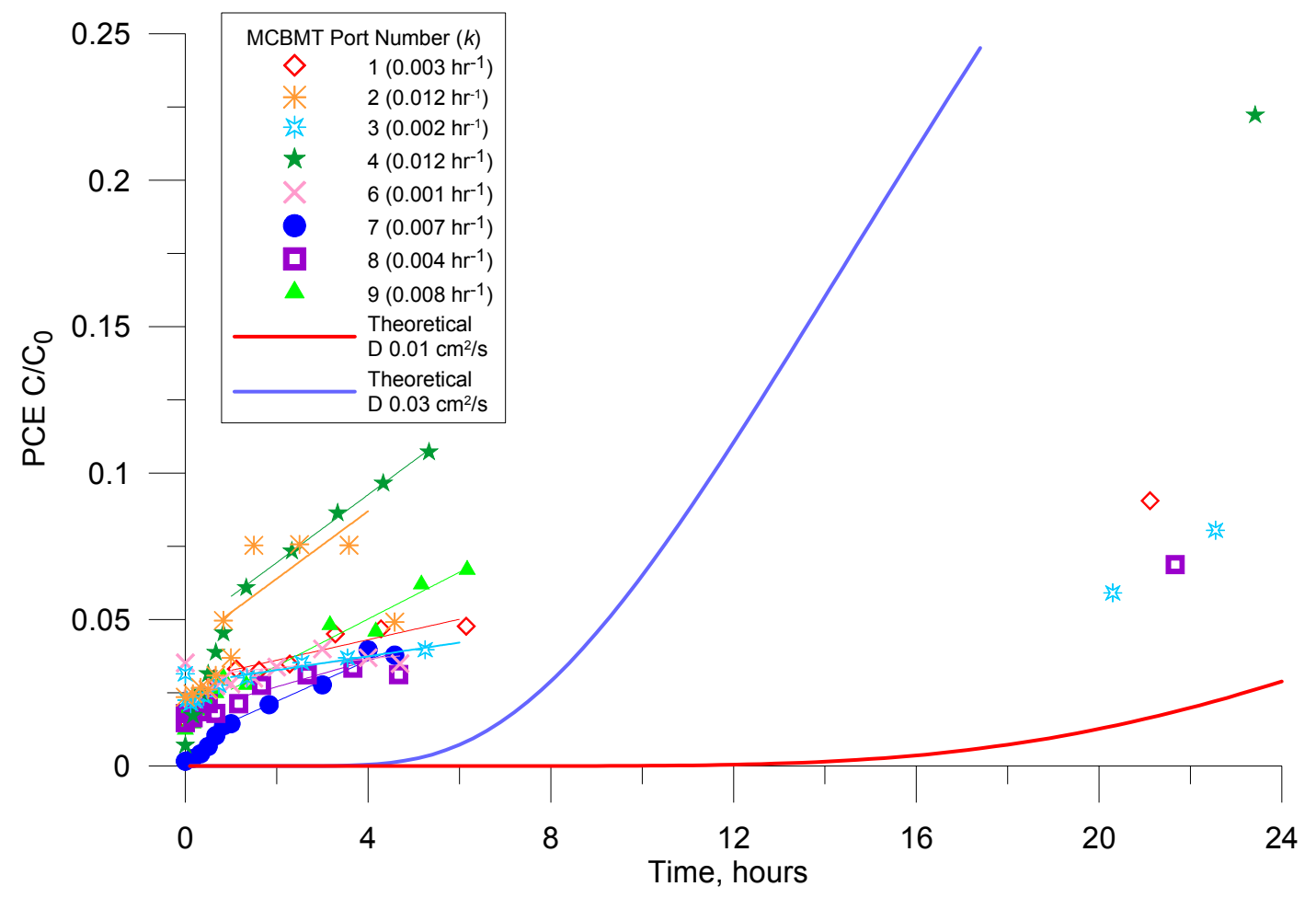

Figure 6 - Normalized PCE Field Concentration Data

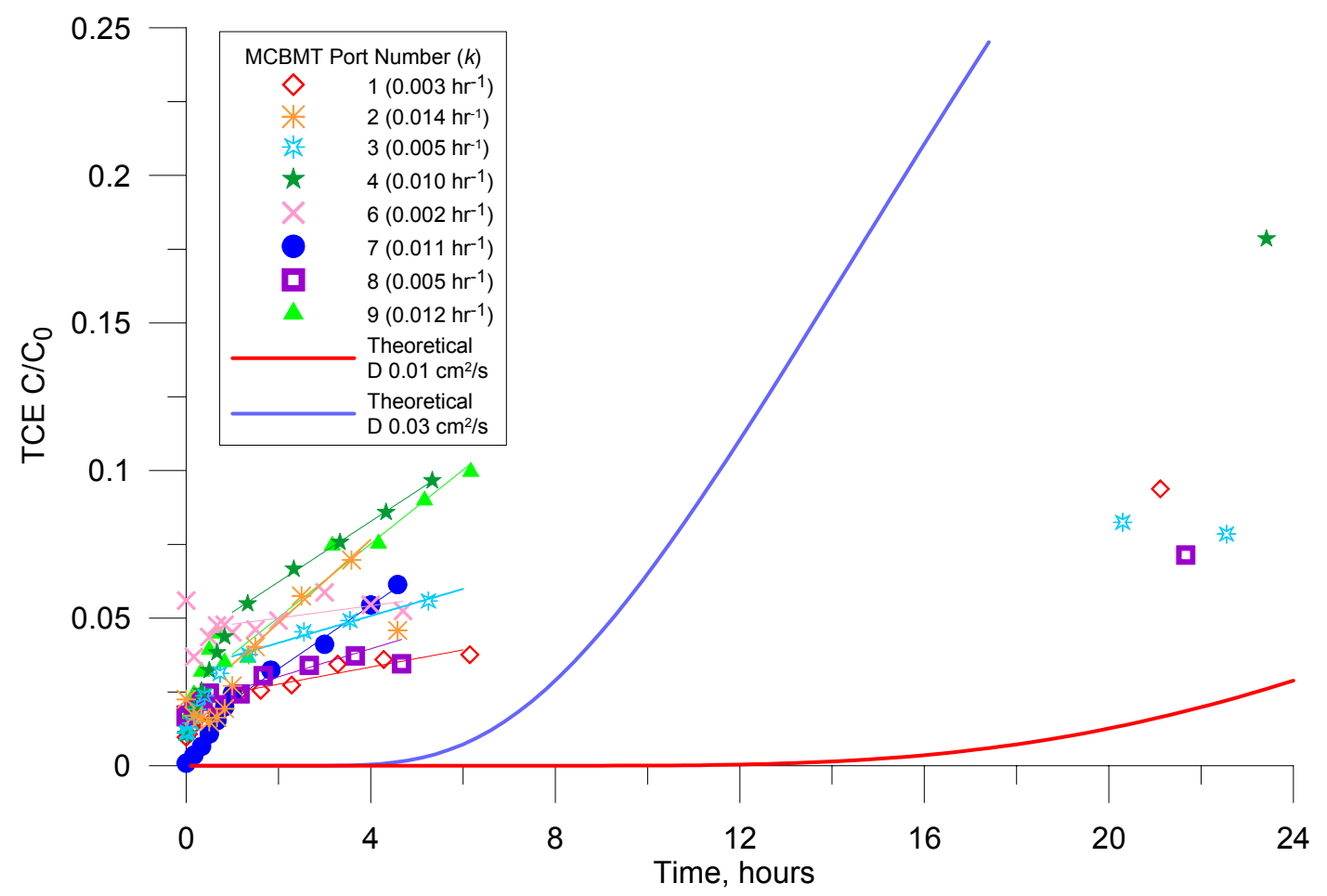

Figure 7 - Normalized TCE Field Concentration Data 
Table 4 - Summary of Diffusion Coefficients Due to Mass Transfer $\left(D_{m t}\right)$

\begin{tabular}{|c|r|c|r|r|r|r|r|r|}
\hline ID & $\begin{array}{c}\text { PCE } D_{m t} \\
\mathrm{~cm}^{2} / \mathrm{s}\end{array}$ & $\mathrm{R}^{2}$ & $\begin{array}{c}\text { PCE } \mathrm{C}_{0} \\
\mathrm{ppmv}\end{array}$ & $\begin{array}{c}\text { PCE } \mathrm{C}_{0} \\
\mathrm{mg} / \mathrm{m}^{3}\end{array}$ & $\begin{array}{c}\text { TCE } D_{m t} \\
\mathrm{~cm}^{2} / \mathrm{s}\end{array}$ & $\mathrm{R}^{2}$ & $\begin{array}{c}\text { TCE } \mathrm{C}_{0} \\
\mathrm{ppmv}\end{array}$ & $\begin{array}{c}\mathrm{TCE} \mathrm{C}_{0} \\
\mathrm{mg} / \mathrm{m}^{3}\end{array}$ \\
\hline MCBMT-1 & 0.0097 & 0.82 & 3.6 & 24.4 & 0.0081 & 0.89 & 17.1 & 91.8 \\
\hline MCBMT-2 & 0.0320 & 0.53 & 4.3 & 29.2 & 0.0391 & 0.98 & 4.3 & 23.1 \\
\hline MCBMT-3 & 0.0065 & 0.93 & 0.6 & 3.9 & 0.0127 & 0.98 & 0.5 & 2.5 \\
\hline MCBMT-4 & 0.0322 & 1.00 & 63.9 & 433.1 & 0.0285 & 1.00 & 177.0 & 950.5 \\
\hline MCBMT-5 & & & & & & & & \\
\hline MCBMT-6 & 0.0042 & 0.29 & 2.3 & 15.5 & 0.0058 & 0.33 & 2.1 & 11.3 \\
\hline MCBMT-7 & 0.0194 & 0.91 & 3.3 & 22.6 & 0.0298 & 0.98 & 732.0 & 3930.8 \\
\hline MCBMT-8 & 0.0125 & 0.88 & 250.0 & 1694.5 & 0.0132 & 0.91 & 288.5 & 1549.2 \\
\hline MCBMT-9 & 0.0222 & 0.94 & 2.8 & 19.0 & 0.0347 & 0.94 & 17.0 & 91.1 \\
\hline
\end{tabular}

\section{Mass Flux Determination}

Based on the assumption that solvent migration in the 'upland unit' is primarily driven by diffusion, the $D_{m t}$ can be used with basic diffusion theory to estimate mass flux to the groundwater. In addition, the mass flux can be compared with removal rates of remedial activities (i.e. soil vapor extraction).

Based on Fick's First Law of Diffusion, we assume one-dimensional diffusion in a homogenous, semi-infinite porous medium and approximate the flux as

$$
J_{D} \approx-\theta_{a} D_{m t} \frac{\Delta C}{\Delta z} \quad \text { Equation 2 }
$$

$J_{d}=$ diffusive flux $\left(\mathrm{mg} / \mathrm{m}^{2} / \mathrm{s}\right)$

$\theta_{a}=$ air filled porosity

$D_{m t}=$ field mass transfer diffusion coefficient $\left(\mathrm{m}^{2} / \mathrm{s}\right)$

$C=$ concentration $\left(\mathrm{mg} / \mathrm{m}^{3}\right)$

$z=$ distance $(m)$

Since $D_{m t}$ is a site specific field measurement, we assume the coefficient takes into account the porous media properties that would control the flux (tortuosity, retardation, etc.). For the Miscellaneous Chemical Basin, $\theta_{a}=0.17$ based on geophysical measurements provided in Appendix C. $\Delta z=20 \mathrm{ft}$ is based on interpretation of lithology logs indicating that this is the depth where higher permeability begins and presumably where the majority of the PSVE flow would occur. $C_{0}$ was used for $\Delta C$ (i.e. $C_{2}=0$ ) which would provide the most conservative (highest) mass flux. 
The point flux calculation input and results using Equation 2 with $\theta_{a}=0.17$ and $\Delta \mathrm{z}=20 \mathrm{ft}$ are provided in Table 5 and Table 6 . Golden Software's Surfer ${ }^{\circledR}$ program was used to contour $J_{d}$. and to integrate the contour grid file to calculate the total mass flux over the area. Surfer approximates the necessary onedimensional integrals using three classical numerical integration algorithms: extended trapezoidal rule, extended Simpson's rule, and extended Simpson's 3/8 rule. The volume results are reported in cubic units. For integrating $J_{d}\left(\mathrm{lb} / \mathrm{ft}^{2} / \mathrm{yr}\right)$ over the area using SRS coordinates in feet, the units are $\mathrm{ft} \cdot \mathrm{ft}^{\circ} \mathrm{lb} / \mathrm{ft}^{2} / \mathrm{yr}=\mathrm{lb} / \mathrm{yr}$. The diffusive flux contour plots are provided in Figure 8 with an overlay of the mass transfer diffusion coefficient $\left(D_{m t}\right)$ contour. From this analysis, the current yearly diffusive flux is $2.9 \mathrm{lb} / \mathrm{yr}$ TCE and $0.9 \mathrm{lb} / \mathrm{yr}$ PCE. In comparison, the estimated removal by the 10 PSVE wells in and just surrounding the integrated area was $2.1 \mathrm{lb} / \mathrm{yr}$ TCE and $1.2 \mathrm{lb} / \mathrm{yr}$ PCE. The PSVE removal rates were estimated from the 2004 average well concentration (1.2 ppmv TCE and 0.6 ppmv PCE) using a continuous average flow rate of $1 \mathrm{cfm}$ per well. These results are summarized in Table 7.

Table 5 - Flux Calculation Results for TCE

\begin{tabular}{|c|c|c|c|c|c|c|c|c|}
\hline ID & $\begin{array}{c}\text { TCE } D_{m t} \\
\mathrm{~cm}^{2} / \mathrm{s}\end{array}$ & $\begin{array}{c}\text { TCE } D_{m t} \\
\mathrm{ft}^{2} / \mathrm{s}\end{array}$ & $\begin{array}{c}C_{0} \\
\text { ppmv }\end{array}$ & $\begin{array}{c}C_{0} \\
\mathrm{mg} / \mathrm{m}^{3}\end{array}$ & $\begin{array}{c}C_{0} \\
\mathrm{Mg} / \mathrm{ft}^{3}\end{array}$ & $\begin{array}{c}J_{d} \\
\mathrm{mg} / \mathrm{ft}^{2} / \mathrm{s}\end{array}$ & $\begin{array}{c}J_{d} \\
\mathrm{mg} / \mathrm{ft}^{2} / \mathrm{yr}\end{array}$ & $\begin{array}{c}J_{d} \\
\mathrm{lb} / \mathrm{ft}^{2} / \mathrm{yr}\end{array}$ \\
\hline MCBMT-1 & 0.0081 & $8.68 \mathrm{E}-06$ & 17.1 & 91.8 & 2.60 & $1.92 \mathrm{E}-07$ & 6.05 & 1.33E-05 \\
\hline MCBMT-2 & 0.0391 & $4.21 \mathrm{E}-05$ & 4.3 & 23.1 & 0.65 & $2.35 \mathrm{E}-07$ & 7.40 & 1.63E-05 \\
\hline ИCВMT-3 & 0.0127 & 1.36E-05 & 0.5 & 2.5 & 0.07 & 8.31E-09 & 0.26 & $5.77 \mathrm{E}-07$ \\
\hline MCBMT-4 & 0.0285 & 3.07E-05 & 177.0 & 950.5 & 26.90 & 7.01E-06 & 221.19 & 4.88E-04 \\
\hline \multicolumn{9}{|l|}{ MCBMT-5 } \\
\hline MCBMT-6 & 0.0058 & $6.25 \mathrm{E}-06$ & 2.1 & 11.3 & 0.32 & $1.70 \mathrm{E}-08$ & 0.53 & $1.18 \mathrm{E}-06$ \\
\hline MCBMT-7 & 0.0298 & $3.21 \mathrm{E}-05$ & 732.0 & 3930.8 & 111.24 & $3.03 E-05$ & 955.84 & $2.11 \mathrm{E}-03$ \\
\hline MCBMT-8 & 0.0132 & 1.42E-05 & 288.5 & 1549.2 & 43.84 & $5.29 \mathrm{E}-06$ & 166.76 & 3.68E-04 \\
\hline MCBMT-9 & 0.0347 & 3.74E-05 & 17.0 & 91.1 & 2.58 & 8.19E-07 & 25.83 & 5.69E-05 \\
\hline
\end{tabular}

Table 6 - Flux Calculation Results for PCE

\begin{tabular}{|c|c|c|c|c|c|c|c|c|}
\hline ID & $\begin{array}{c}\mathrm{PCE} D_{m \mathrm{t}} \\
\mathrm{cm}^{2} / \mathrm{s}\end{array}$ & $\begin{array}{c}\mathrm{PCE} D_{m \mathrm{t}} \\
\mathrm{ft}^{2} / \mathrm{s}\end{array}$ & $\begin{array}{c}C_{0} \\
\mathrm{ppmv}\end{array}$ & $\begin{array}{c}C_{0} \\
\mathrm{mg} / \mathrm{m}^{3}\end{array}$ & $\begin{array}{c}C_{0} \\
\mathrm{Mg} / \mathrm{ft}^{3}\end{array}$ & $\begin{array}{c}J_{d} \\
\mathrm{mg} / \mathrm{ft}^{2} / \mathrm{s}\end{array}$ & $\begin{array}{c}J_{d} \\
\mathrm{mg} / \mathrm{ft}^{2} / \mathrm{yr}\end{array}$ & $\begin{array}{c}J_{d} \\
\mathrm{lb} / \mathrm{ft}^{2} / \mathrm{yr}\end{array}$ \\
\hline MCBMT-1 & 0.0097 & $1.04 \mathrm{E}-05$ & 3.6 & 24.4 & 0.69 & $6.13 \mathrm{E}-08$ & 1.93 & $4.26 \mathrm{E}-06$ \\
\hline MCBMT-2 & 0.0320 & $3.45 \mathrm{E}-05$ & 4.3 & 29.2 & 0.83 & $2.42 \mathrm{E}-07$ & 7.64 & 1.68E-05 \\
\hline MCBMT-3 & 0065 & 7.03E-06 & 0.6 & 3.9 & 0.11 & $6.62 \mathrm{E}-09$ & 0.21 & $4.60 \mathrm{E}-07$ \\
\hline MCBMT-4 & 0.0322 & $3.46 \mathrm{E}-05$ & 63.9 & 433.1 & 12.26 & $3.61 \mathrm{E}-06$ & 113.77 & $2.51 \mathrm{E}-04$ \\
\hline \multicolumn{9}{|l|}{ MCBMT-5 } \\
\hline MCBMT-6 & 0.0042 & $4.48 \mathrm{E}-06$ & 2.3 & 15.5 & 0.44 & 1.66E-08 & 0.52 & 1.16E-06 \\
\hline MCBMT-7 & 0.0194 & $2.08 \mathrm{E}-05$ & 3.3 & 22.6 & 0.64 & 1.14E-07 & 3.58 & 7.89E-06 \\
\hline MCBMT-8 & 0.0125 & 1.35E-05 & 250.0 & 1694.5 & 47.95 & $5.48 \mathrm{E}-06$ & 172.95 & $3.81 \mathrm{E}-04$ \\
\hline MCBMT-9 & 0.0222 & $2.39 \mathrm{E}-05$ & 2.8 & 19.0 & 0.54 & 1.09E-07 & 3.44 & 7.59E-06 \\
\hline
\end{tabular}


WSRC-TR-2005-00266

MCB Mass Transfer Testing [Page 17]

Table 7 - Comparison of Diffusive Mass Flux and PSVE Removal

\begin{tabular}{|c|c|c|}
\hline Compound & $\begin{array}{c}\text { Diffusive Mass Flux } J_{d} \\
\mathrm{lb} / \mathrm{yr}\end{array}$ & $\begin{array}{c}2004 \text { Estimated PSVE removal } \\
\mathrm{lb} / \mathrm{yr}\end{array}$ \\
\hline TCE & 2.9 & 2.1 \\
\hline PCE & 0.9 & 1.2 \\
\hline
\end{tabular}


WSRC-TR-2005-00266 MCB Mass Transfer Testing [Page 18]
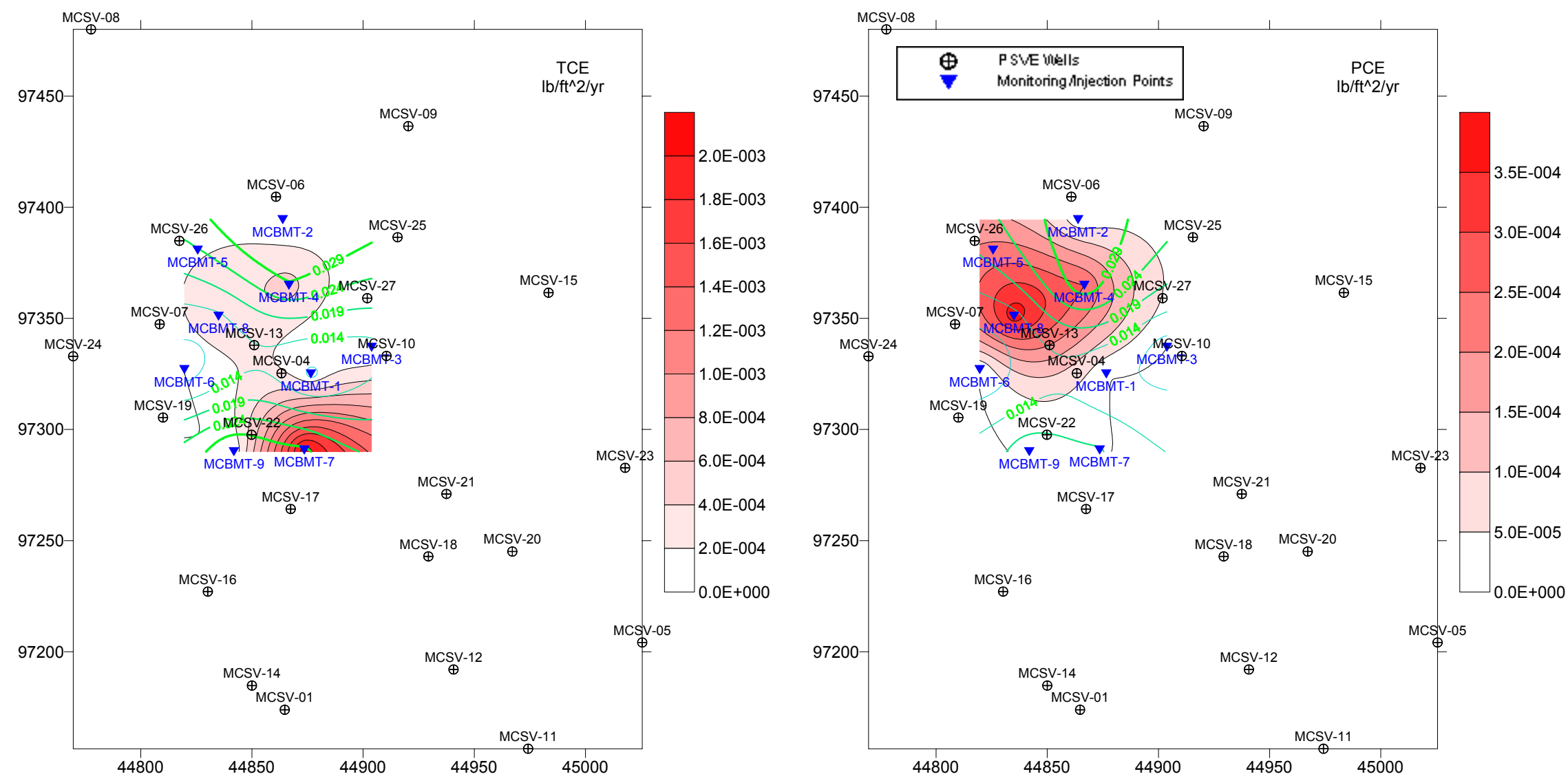

Figure 8 - Mass Flux (filled) and Mass Transfer Diffusion Coefficient Contours in $\mathrm{cm}^{2} / \mathrm{s}$ (not filled) 


\section{Summary and Conclusions}

The field mass transfer test developed and evaluated during this study provides a realistic measure of solvent release from fine grain sediments in the vadose zone. Comparison of the measured mass flux and PSVE removal rate validate the field and calculation protocols. The field test is easily applied and the data reduction and interpretation is straightforward.

The mass flux can be used to determine the appropriate intensity of SVE to break the path between the vadose zone source areas and the groundwater. Lower flux rates will dictate passive SVE while higher flux rates will require more aggressive active SVE. For the MCB, passive SVE is the appropriate remedy at this time.

The measured mass flux can be used in conjunction with groundwater flow and mixing models to determine the resulting groundwater concentration and end state for vadose solvent remediation.

\section{References}

Crank, J. 1956. The Mathematics of Diffusion. Oxford, Clarendon Press.

EPA. 1995. Bioventing Principles and Practices, Volume II: Bioventing Design. U. S. Evironmental Protection Agency. EPA/540/R-95/534b.

Johnson, P. C., C. Bruce, R. L. Johnson and M. W. Kemblowski. 1998. "In Situ Measurement of Effective Vapor-Phase Porous Media Diffusion Coefficients." Environmental Science and Technology 32: 3405-3409.

Schwarzenbach, R. P., P. M. Gschwend and D. M. Imboden. 1993. Environmental Organic Chemistry, John Wiley \& Sons, Inc. 


\section{Appendix A - Sediment Analysis Results}

Table 8 - Sediment VOC Concentration $(\mathrm{mg} / \mathrm{kg})$ from Installation of MCBMT Injection/Sample Ports

\begin{tabular}{|c|c|c|c|c|c|c|c|c|c|c|c|c|c|c|c|}
\hline Sample ID & $\begin{array}{c}\text { Sample } \\
\text { Date }\end{array}$ & Depth, $\mathrm{ft}$ & BENZ & CCL4 & C-DCE & CFC11 & CHCL3 & FR113 & MECL & $\mathrm{MEOH}$ & PCE & TCA & TCE & T-DCE & TOL \\
\hline MCBMT-1-04 & $3 / 16 / 2004$ & 4 & - & - & - & - & - & - & - & - & $<0.003$ & - & - & - & - \\
\hline MCBMT-1-04 & $3 / 16 / 2004$ & 4 & - & - & - & $<0.003$ & - & - & - & - & $<0.003$ & - & - & - & - \\
\hline MCBMT-1-05 & $3 / 16 / 2004$ & 5 & - & - & - & - & - & - & - & - & $<0.003$ & - & - & - & - \\
\hline MCBMT-1-05 & $3 / 16 / 2004$ & 5 & - & - & - & $<0.003$ & - & - & - & - & $<0.003$ & - & - & - & - \\
\hline MCBMT-1-06 & $3 / 16 / 2004$ & 6 & - & - & - & - & - & - & - & - & $<0.003$ & - & - & - & - \\
\hline MCBMT-1-06 & $3 / 16 / 2004$ & 6 & - & - & - & - & - & - & - & - & $<0.003$ & - & - & - & - \\
\hline MCBMT-1-07 & $3 / 16 / 2004$ & 7 & - & - & - & - & - & - & - & - & $<0.003$ & - & - & - & - \\
\hline MCBMT-1-07 & $3 / 16 / 2004$ & 7 & - & - & - & $<0.003$ & - & - & - & - & $<0.003$ & - & - & - & - \\
\hline MCBMT-1-08 & $3 / 16 / 2004$ & 8 & - & $<0.003$ & - & - & - & - & - & - & $<0.003$ & - & $<0.003$ & - & - \\
\hline MCBMT-1-08 & $3 / 16 / 2004$ & 8 & - & $<0.003$ & - & - & - & - & - & - & $<0.003$ & - & 0.003 & - & - \\
\hline MCBMT-1-09 & $3 / 16 / 2004$ & 9 & - & $<0.003$ & - & - & - & - & - & - & $<0.003$ & - & 0.006 & - & - \\
\hline MCBMT-1-09 & $3 / 16 / 2004$ & 9 & - & $<0.003$ & - & - & - & - & - & - & $<0.003$ & - & 0.005 & - & - \\
\hline MCBMT-1-10 & $3 / 16 / 2004$ & 10 & - & $<0.003$ & - & - & - & - & - & - & $<0.003$ & - & 0.012 & - & - \\
\hline MCBMT-1-10 & $3 / 16 / 2004$ & 10 & - & $<0.003$ & - & - & - & - & - & - & $<0.003$ & - & 0.014 & - & - \\
\hline MCBMT-2-05 & $3 / 16 / 2004$ & 5 & - & \begin{tabular}{|c|}
- \\
\end{tabular} & - & - & - & - & - & - & $<0.003$ & - & - & - & - \\
\hline MCBMT-2-05 & $3 / 16 / 2004$ & 5 & - & - & - & - & - & - & - & - & $<0.003$ & - & - & - & - \\
\hline MCBMT-2-06 & $3 / 16 / 2004$ & 6 & - & - & - & - & - & - & - & - & 0.010 & - & - & - & - \\
\hline MCBMT-2-06 & $3 / 16 / 2004$ & 6 & - & - & - & - & - & - & - & - & 0.014 & - & $<0.003$ & - & - \\
\hline MCBMT-2-07 & $3 / 16 / 2004$ & 7 & - & - & - & - & - & - & - & - & 0.008 & - & - & - & - \\
\hline MCBMT-2-07 & $3 / 16 / 2004$ & 7 & - & - & - & - & - & - & - & - & 0.004 & - & $<0.003$ & - & - \\
\hline MCBMT-2-08 & $3 / 16 / 2004$ & 8 & - & - & - & - & - & - & - & - & 0.007 & - & - & - & - \\
\hline MCBMT-2-08 & $3 / 16 / 2004$ & 8 & - & - & - & - & - & - & - & - & 0.004 & - & $<0.003$ & - & - \\
\hline MCBMT-2-09 & $3 / 16 / 2004$ & 9 & - & - & - & - & - & - & - & - & $<0.003$ & - & $<0.003$ & - & - \\
\hline MCBMT-2-09 & $3 / 16 / 2004$ & 9 & - & $<0.003$ & - & - & - & - & - & - & 0.007 & - & $<0.003$ & - & - \\
\hline
\end{tabular}


WSRC-TR-2005-00266 MCB Mass Transfer Testing [Page 21]

\begin{tabular}{|c|c|c|c|c|c|c|c|c|c|c|c|c|c|c|c|}
\hline Sample ID & $\begin{array}{c}\text { Sample } \\
\text { Date }\end{array}$ & Depth, ft & BENZ & CCL4 & C-DCE & CFC11 & CHCL3 & FR113 & MECL & $\mathrm{MEOH}$ & PCE & TCA & TCE & T-DCE & TOL \\
\hline MCBMT-2-10 & $3 / 16 / 2004$ & 10 & - & $<0.003$ & - & - & - & - & - & - & 0.004 & - & $<0.003$ & - & - \\
\hline MCВMT-2-10 & $3 / 16 / 2004$ & 10 & - & $<0.003$ & - & - & - & - & - & - & 0.008 & - & $<0.003$ & - & - \\
\hline MCВMT-2-11 & $3 / 16 / 2004$ & 11 & - & $<0.003$ & - & - & - & - & - & - & 0.004 & - & $<0.003$ & - & - \\
\hline MCВМТ-2-11 & $3 / 16 / 2004$ & 11 & - & $<0.003$ & - & - & - & - & - & - & 0.007 & - & 0.005 & - & - \\
\hline MCBMT-2-12 & $3 / 16 / 2004$ & 12 & - & $<0.003$ & - & - & - & - & - & - & 0.004 & - & 0.004 & - & - \\
\hline MCВMT-2-12 & $3 / 16 / 2004$ & 12 & - & $<0.003$ & - & - & - & - & - & - & 0.007 & - & 0.007 & - & - \\
\hline МСВМТ-3-06 & $3 / 17 / 2004$ & 6 & - & - & - & - & - & - & - & - & - & - & - & - & - \\
\hline MCВMT-3-06 & $3 / 17 / 2004$ & 6 & - & - & - & - & - & - & - & - & - & - & - & - & - \\
\hline MCВMT-3-07 & $3 / 17 / 2004$ & 7 & - & - & - & - & - & - & - & - & - & - & - & - & - \\
\hline MCВMT-3-07 & $3 / 17 / 2004$ & 7 & - & - & - & - & - & - & - & - & - & - & - & - & - \\
\hline МСВМТ-3-08 & $3 / 17 / 2004$ & 8 & - & - & - & - & - & - & - & - & - & - & - & - & - \\
\hline MCВMT-3-08 & $3 / 17 / 2004$ & 8 & - & - & - & - & - & - & - & - & $<0.003$ & - & - & - & - \\
\hline МСВМТ-3-09 & $3 / 17 / 2004$ & 9 & - & - & - & - & - & - & - & - & $<0.003$ & - & - & - & - \\
\hline МСВМТ-3-09 & $3 / 17 / 2004$ & 9 & - & - & - & - & - & - & - & - & $<0.003$ & - & - & - & - \\
\hline МСВМТ-3-10 & $3 / 17 / 2004$ & 10 & - & - & - & - & - & - & - & - & - & - & - & - & - \\
\hline МСВМТ-3-10 & $3 / 17 / 2004$ & 10 & - & - & - & - & - & - & - & - & - & - & - & - & - \\
\hline MCBMT-4-05 & $3 / 17 / 2004$ & 5 & - & 0.019 & - & $<0.003$ & 0.045 & - & - & - & 2.671 & 0.010 & 3.891 & - & - \\
\hline MCВMT-4-05 & $3 / 17 / 2004$ & 5 & - & 0.024 & $<0.13$ & $<0.003$ & 0.080 & - & - & - & 3.927 & $<0.003$ & 5.456 & - & - \\
\hline MCВMT-4-06 & $3 / 17 / 2004$ & 6 & - & 0.044 & - & $<0.003$ & 0.032 & - & - & - & 0.907 & - & 1.605 & - & - \\
\hline MCВMТ-4-06 & $3 / 17 / 2004$ & 6 & - & 0.147 & $<0.13$ & $<0.003$ & 0.055 & - & - & - & 2.226 & 0.049 & 4.773 & 0.16 & - \\
\hline MCВMT-4-07 & $3 / 17 / 2004$ & 7 & - & 0.068 & - & $<0.003$ & \begin{tabular}{|l|}
0.027 \\
\end{tabular} & - & - & - & 1.180 & - & 1.924 & - & - \\
\hline MCВMT-4-07 & $3 / 17 / 2004$ & 7 & - & 0.149 & $<0.13$ & $<0.003$ & 0.053 & - & - & - & 2.278 & $<0.003$ & 3.631 & 0.08 & - \\
\hline МСВМТ-4-08 & $3 / 17 / 2004$ & 8 & - & 0.005 & - & - & 0.010 & - & - & - & 0.086 & - & 0.317 & - & - \\
\hline MCBMT-4-08 & $3 / 17 / 2004$ & 8 & - & 0.055 & - & - & 0.008 & - & - & - & 1.192 & - & 1.309 & 0.06 & - \\
\hline MCBMT-4-09 & $3 / 17 / 2004$ & 9 & - & 0.006 & - & - & 0.008 & - & - & - & 0.072 & - & 0.338 & - & - \\
\hline MCBMT-4-09 & $3 / 17 / 2004$ & 9 & - & 0.008 & - & - & 0.005 & - & - & - & 0.240 & - & 0.412 & $<0.05$ & - \\
\hline MCBMT-4-10 & $3 / 17 / 2004$ & 10 & - & $<0.003$ & - & - & 0.004 & - & - & - & 0.017 & - & 0.101 & - & - \\
\hline MCBMT-4-10 & $3 / 17 / 2004$ & 10 & - & $<0.003$ & - & - & $<0.003$ & - & - & - & 0.029 & - & 0.136 & - & - \\
\hline MCBMT-5-05 & $3 / 17 / 2004$ & 5 & - & $<0.003$ & - & - & $<0.003$ & - & - & - & 1.021 & - & 0.041 & - & - \\
\hline MCВMT-5-05 & $3 / 17 / 2004$ & 5 & - & $<0.003$ & - & 0.004 & - & - & - & - & 1.058 & - & 0.041 & - & - \\
\hline
\end{tabular}


WSRC-TR-2005-00266 MCB Mass Transfer Testing [Page 22]

\begin{tabular}{|c|c|c|c|c|c|c|c|c|c|c|c|c|c|c|c|}
\hline Sample ID & $\begin{array}{c}\text { Sample } \\
\text { Date }\end{array}$ & Depth, ft & BENZ & CCL4 & C-DCE & CFC11 & CHCL3 & FR113 & MECL & $\mathrm{MEOH}$ & PCE & TCA & TCE & T-DCE & TOL \\
\hline MCBMT-5-06 & $3 / 17 / 2004$ & 6 & - & $<0.003$ & - & 0.010 & 0.003 & - & - & - & 3.989 & - & 0.341 & 0.07 & - \\
\hline МСВМТ-5-06 & $3 / 17 / 2004$ & 6 & - & $<0.003$ & - & 0.013 & 0.005 & - & - & - & 3.816 & - & 0.369 & - & - \\
\hline MCВМТ-5-07 & $3 / 17 / 2004$ & 7 & - & $<0.003$ & - & - & $<0.003$ & - & 0.145 & - & 1.091 & - & 0.059 & - & - \\
\hline MCВМТ-5-07 & $3 / 17 / 2004$ & 7 & - & 0.003 & - & 0.005 & 0.003 & - & - & - & 2.659 & - & 0.113 & - & - \\
\hline MCBMT-5-08 & $3 / 17 / 2004$ & 8 & - & $<0.003$ & - & - & - & - & - & - & 0.511 & - & 0.016 & - & - \\
\hline MCВMT-5-08 & $3 / 17 / 2004$ & 8 & - & $<0.003$ & - & $<0.003$ & - & - & - & - & 1.190 & - & 0.034 & - & - \\
\hline MCВМТ-5-09 & $3 / 17 / 2004$ & 9 & - & - & - & - & - & - & - & - & 0.016 & - & $<0.003$ & - & - \\
\hline MCВMT-5-09 & $3 / 17 / 2004$ & 9 & - & - & - & - & - & - & - & - & 0.033 & - & $<0.003$ & - & - \\
\hline MCВMT-5-10 & $3 / 17 / 2004$ & 10 & - & $<0.003$ & - & $<0.003$ & - & - & - & - & 0.033 & - & $<0.003$ & - & - \\
\hline MCВMT-5-10 & $3 / 17 / 2004$ & 10 & - & $<0.003$ & - & - & - & - & - & - & 0.039 & - & 0.004 & - & - \\
\hline MCBMT-6-05 & $3 / 17 / 2004$ & 5 & - & - & - & - & - & - & - & - & - & - & - & - & - \\
\hline MCBMT-6-05 & $3 / 17 / 2004$ & 5 & - & - & - & - & - & - & - & - & $<0.003$ & - & - & - & - \\
\hline MCВMT-6-06 & $3 / 17 / 2004$ & 6 & - & - & - & - & - & - & - & - & - & - & - & - & - \\
\hline МСВМТ-6-06 & $3 / 17 / 2004$ & 6 & - & - & - & - & - & - & - & - & $<0.003$ & - & - & - & - \\
\hline МСВМТ-6-07 & $3 / 17 / 2004$ & 7 & - & - & - & - & - & - & - & - & $<0.003$ & - & - & - & - \\
\hline МСВМТ-6-07 & $3 / 17 / 2004$ & 7 & - & - & - & - & - & - & - & - & $<0.003$ & - & - & - & - \\
\hline MCВMT-6-08 & $3 / 17 / 2004$ & 8 & - & - & - & - & - & - & - & - & - & - & - & - & - \\
\hline MCВMT-6-08 & $3 / 17 / 2004$ & 8 & - & - & - & - & - & - & - & - & $<0.003$ & - & - & - & - \\
\hline МСВМТ-6-09 & $3 / 17 / 2004$ & 9 & - & - & - & - & - & - & - & - & $<0.003$ & - & - & - & - \\
\hline МСВМТ-6-09 & $3 / 17 / 2004$ & 9 & - & - & - & - & - & - & - & - & $<0.003$ & - & $<0.003$ & - & - \\
\hline MCВMT-7-06 & $3 / 17 / 2004$ & 6 & - & 0.042 & - & - & 0.052 & - & - & - & 0.044 & $<0.003$ & 14.425 & - & - \\
\hline МСВМТ-7-06 & $3 / 17 / 2004$ & 6 & - & 0.082 & - & - & 0.081 & - & - & - & 0.069 & $<0.003$ & 24.696 & - & - \\
\hline МСВМТ-7-07 & $3 / 17 / 2004$ & 7 & - & 0.040 & - & - & 0.040 & - & - & - & 0.034 & $<0.003$ & 6.329 & - & - \\
\hline MCВMT-7-07 & $3 / 17 / 2004$ & 7 & - & 0.066 & - & - & 0.047 & - & - & - & 0.053 & - & 9.610 & - & - \\
\hline МСВМТ-7-08 & $3 / 17 / 2004$ & 8 & - & 0.007 & - & - & 0.024 & - & - & - & $<0.003$ & - & 1.835 & - & - \\
\hline МСВMT-7-08 & $3 / 17 / 2004$ & 8 & - & 0.007 & - & - & 0.031 & - & - & - & $<0.003$ & - & 2.615 & - & - \\
\hline МСВМТ-7-09 & $3 / 17 / 2004$ & 9 & - & 0.004 & - & - & 0.013 & - & - & - & $<0.003$ & - & 0.929 & - & - \\
\hline МСВМТ-7-09 & $3 / 17 / 2004$ & 9 & - & 0.004 & - & - & 0.024 & - & - & - & $<0.003$ & - & 1.979 & - & - \\
\hline МСВМТ-7-10 & $3 / 17 / 2004$ & 10 & - & $<0.003$ & - & - & $<0.003$ & - & - & - & $<0.003$ & - & 0.120 & - & - \\
\hline МСВМТ-7-10 & $3 / 17 / 2004$ & 10 & - & $<0.003$ & - & - & $<0.003$ & - & - & - & $<0.003$ & - & 0.236 & - & - \\
\hline
\end{tabular}


WSRC-TR-2005-00266 MCB Mass Transfer Testing [Page 23]

\begin{tabular}{|c|c|c|c|c|c|c|c|c|c|c|c|c|c|c|c|}
\hline Sample ID & $\begin{array}{c}\text { Sample } \\
\text { Date }\end{array}$ & Depth, ft & BENZ & CCL4 & C-DCE & CFC11 & CHCL3 & FR113 & MECL & $\mathrm{MEOH}$ & PCE & TCA & TCE & T-DCE & TOL \\
\hline MCBMT-8-05 & $3 / 17 / 2004$ & 5 & - & $<0.003$ & - & \begin{tabular}{|l|}
1.152 \\
\end{tabular} & \begin{tabular}{|l|}
0.027 \\
\end{tabular} & \begin{tabular}{|l|}
- \\
\end{tabular} & - & \begin{tabular}{|l|}
- \\
\end{tabular} & 7.222 & $<0.003$ & 7.010 & - & - \\
\hline MCBMT-8-05 & $3 / 17 / 2004$ & 5 & - & $<0.003$ & - & 0.556 & 0.030 & 0.011 & - & - & 7.094 & $<0.003$ & 8.148 & - & - \\
\hline MCBMT-8-06 & $3 / 17 / 2004$ & 6 & - & - & - & - & 0.004 & - & - & - & 0.100 & - & 0.284 & - & - \\
\hline MCBMT-8-06 & $3 / 17 / 2004$ & 6 & - & - & - & 0.042 & 0.005 & - & - & - & 0.190 & - & 0.399 & - & - \\
\hline МСВМТ-8-07 & $3 / 17 / 2004$ & 7 & - & $<0.003$ & - & 0.031 & 0.006 & - & - & - & 0.094 & - & 0.384 & - & - \\
\hline MCBMT-8-07 & $3 / 17 / 2004$ & 7 & - & $<0.003$ & - & - & 0.005 & - & - & - & 0.102 & - & 0.319 & - & - \\
\hline MCBMT-8-08 & $3 / 17 / 2004$ & 8 & - & $<0.003$ & - & 0.005 & 0.004 & - & - & - & 0.055 & - & 0.115 & - & - \\
\hline MCBMT-8-08 & $3 / 17 / 2004$ & 8 & - & $<0.003$ & - & - & 0.004 & - & - & - & 0.082 & - & 0.156 & - & - \\
\hline MCBMT-8-09 & $3 / 17 / 2004$ & 9 & - & $<0.003$ & - & 0.007 & 0.003 & - & - & - & 0.100 & - & 0.135 & - & - \\
\hline MCBMT-8-09 & $3 / 17 / 2004$ & 9 & - & $<0.003$ & - & 0.006 & 0.004 & - & - & - & 0.104 & - & 0.146 & - & - \\
\hline MCBMT-9-05 & $3 / 17 / 2004$ & 5 & - & - & - & - & - & - & - & - & 0.055 & - & 0.004 & - & - \\
\hline МСВМТ-9-05 & $3 / 17 / 2004$ & 5 & - & - & - & - & - & - & - & - & 0.049 & - & 0.003 & - & - \\
\hline МСВМТ-9-06 & $3 / 17 / 2004$ & 6 & - & $<0.003$ & - & - & $<0.003$ & - & - & - & 0.054 & - & 0.006 & - & - \\
\hline MCBMT-9-06 & $3 / 17 / 2004$ & 6 & - & $<0.003$ & - & - & - & - & - & - & 0.065 & - & 0.007 & - & - \\
\hline MCBMT-9-07 & $3 / 17 / 2004$ & 7 & - & $<0.003$ & - & - & $<0.003$ & - & - & - & 0.019 & - & 0.005 & - & - \\
\hline MCВMT-9-07 & $3 / 17 / 2004$ & 7 & - & $<0.003$ & - & - & - & - & - & - & 0.011 & - & 0.006 & - & - \\
\hline МСВМТ-9-08 & $3 / 17 / 2004$ & 8 & - & $<0.003$ & - & - & $<0.003$ & - & - & - & 0.007 & - & 0.006 & - & - \\
\hline MCВMT-9-08 & $3 / 17 / 2004$ & 8 & - & $<0.003$ & - & - & $<0.003$ & - & - & - & 0.015 & - & 0.011 & - & - \\
\hline MCBMT-9-09 & $3 / 17 / 2004$ & 9 & - & $<0.003$ & - & - & $<0.003$ & - & - & - & 0.006 & - & 0.010 & - & - \\
\hline MCВМТ-9-09 & $3 / 17 / 2004$ & 9 & - & $<0.003$ & - & - & - & - & - & - & 0.006 & - & 0.009 & - & - \\
\hline МСВМТ-9-10 & $3 / 17 / 2004$ & 10 & - & 0.004 & - & - & $<0.003$ & - & - & - & 0.005 & - & 0.012 & - & - \\
\hline MCBMT-9-10 & $3 / 17 / 2004$ & 10 & - & 0.003 & - & - & $<0.003$ & - & - & - & 0.003 & - & 0.013 & - & - \\
\hline MCВMT-9-11 & $3 / 17 / 2004$ & 11 & - & 0.003 & - & - & $<0.003$ & - & - & - & $<0.003$ & - & 0.012 & - & - \\
\hline MCBMT-9-11 & $3 / 17 / 2004$ & 11 & - & 0.004 & - & - & $<0.003$ & - & - & - & $<0.003$ & - & 0.017 & - & - \\
\hline MCBMT-9-12 & $3 / 17 / 2004$ & 12 & - & $<0.003$ & - & - & $<0.003$ & - & - & - & $<0.003$ & - & 0.003 & - & - \\
\hline MCBMT-9-12 & $3 / 17 / 2004$ & 12 & - & $<0.003$ & - & - & - & - & - & - & $<0.003$ & - & 0.004 & - & - \\
\hline
\end{tabular}


WSRC-TR-2005-00266

MCB Mass Transfer Testing [Page 24]
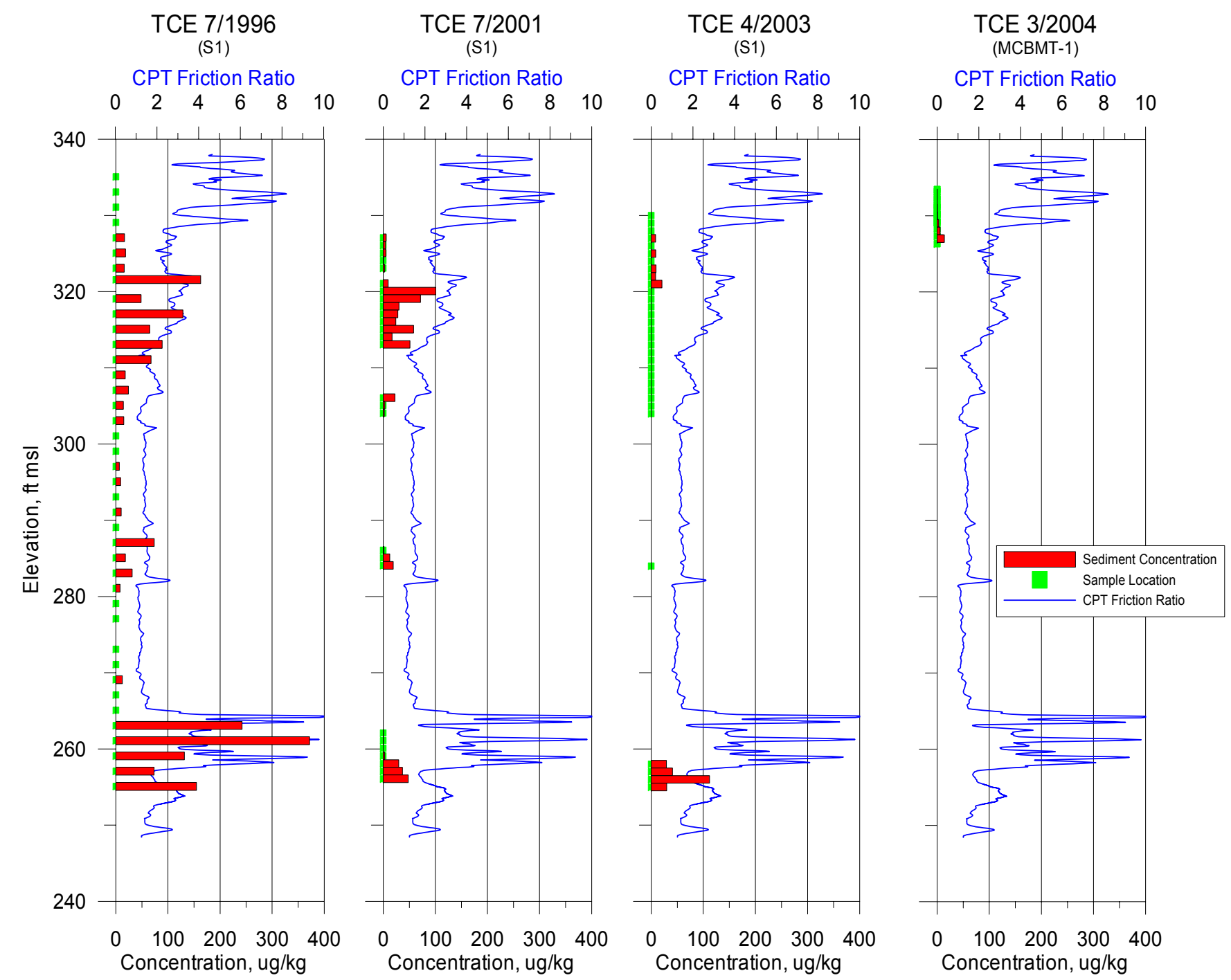

Figure 9 - Temporal Sediment Concentration at Location 1 
WSRC-TR-2005-00266

MCB Mass Transfer Testing [Page 25]

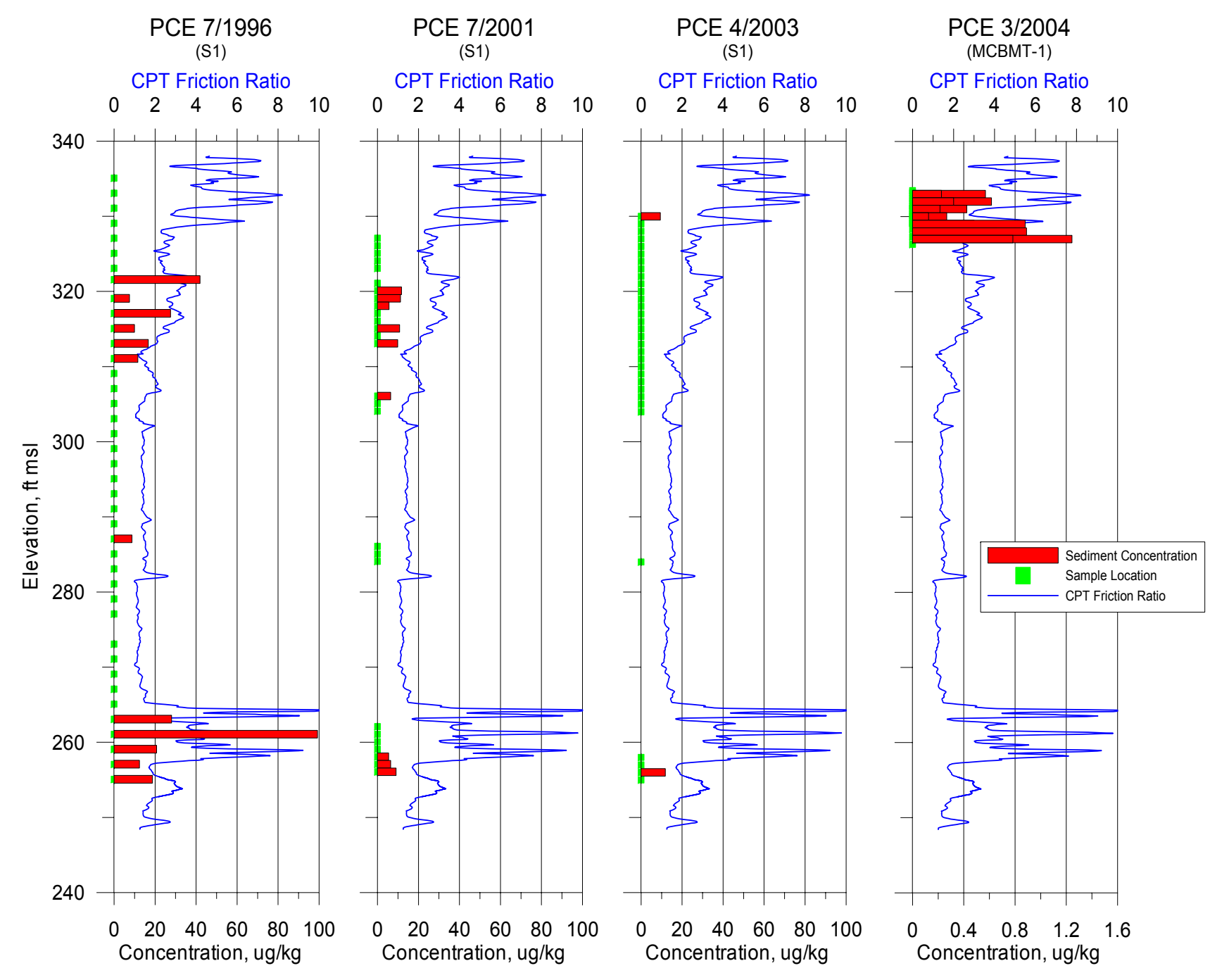

Figure 10 - PCE Temporal Sediment Concentration at Location 1 
WSRC-TR-2005-00266

MCB Mass Transfer Testing [Page 26]

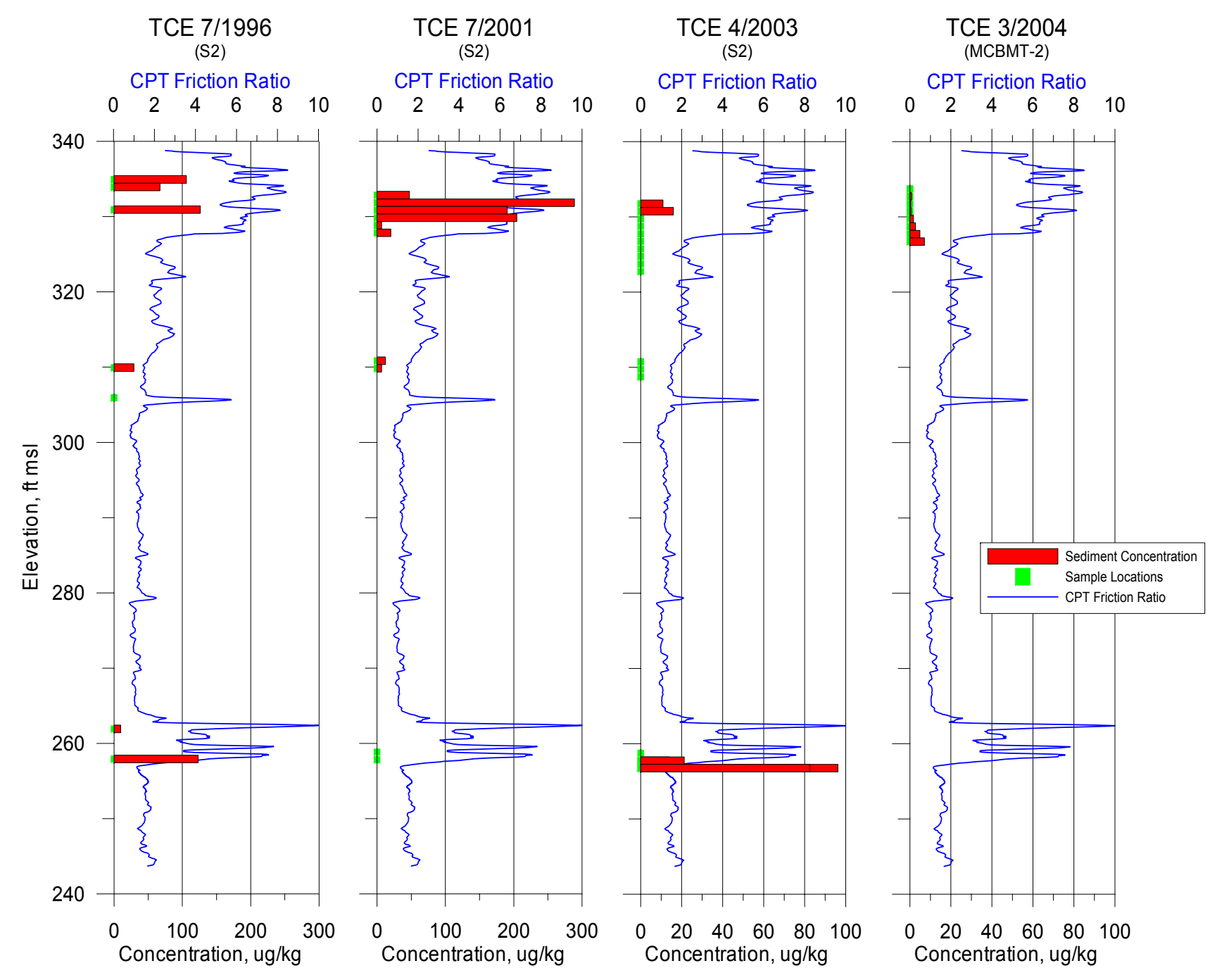

Figure 11 - TCE Temporal Sediment Concentration at Location 2 
WSRC-TR-2005-00266

MCB Mass Transfer Testing [Page 27]
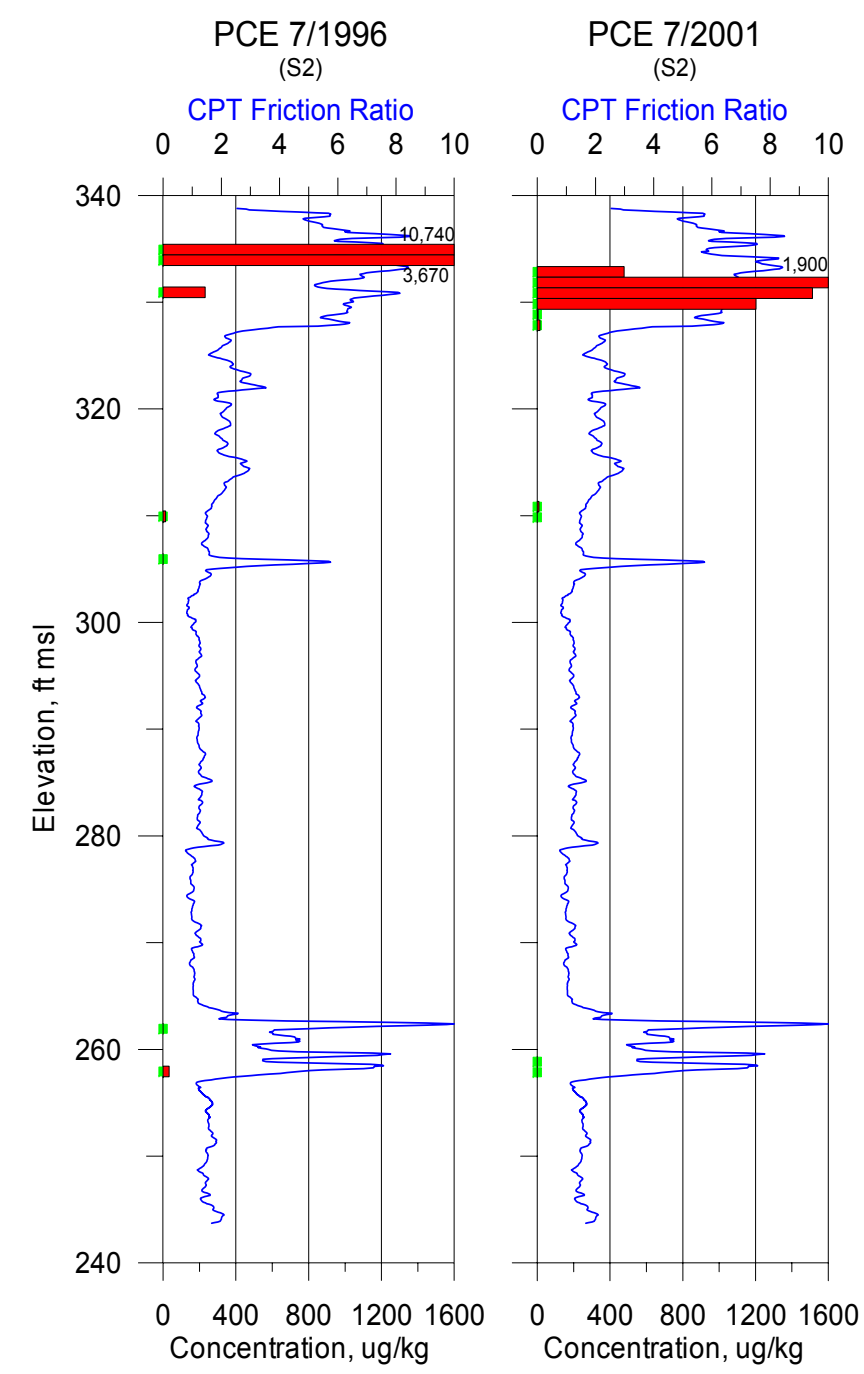
PCE 4/2003
(S2)
CPT Friction Ratio
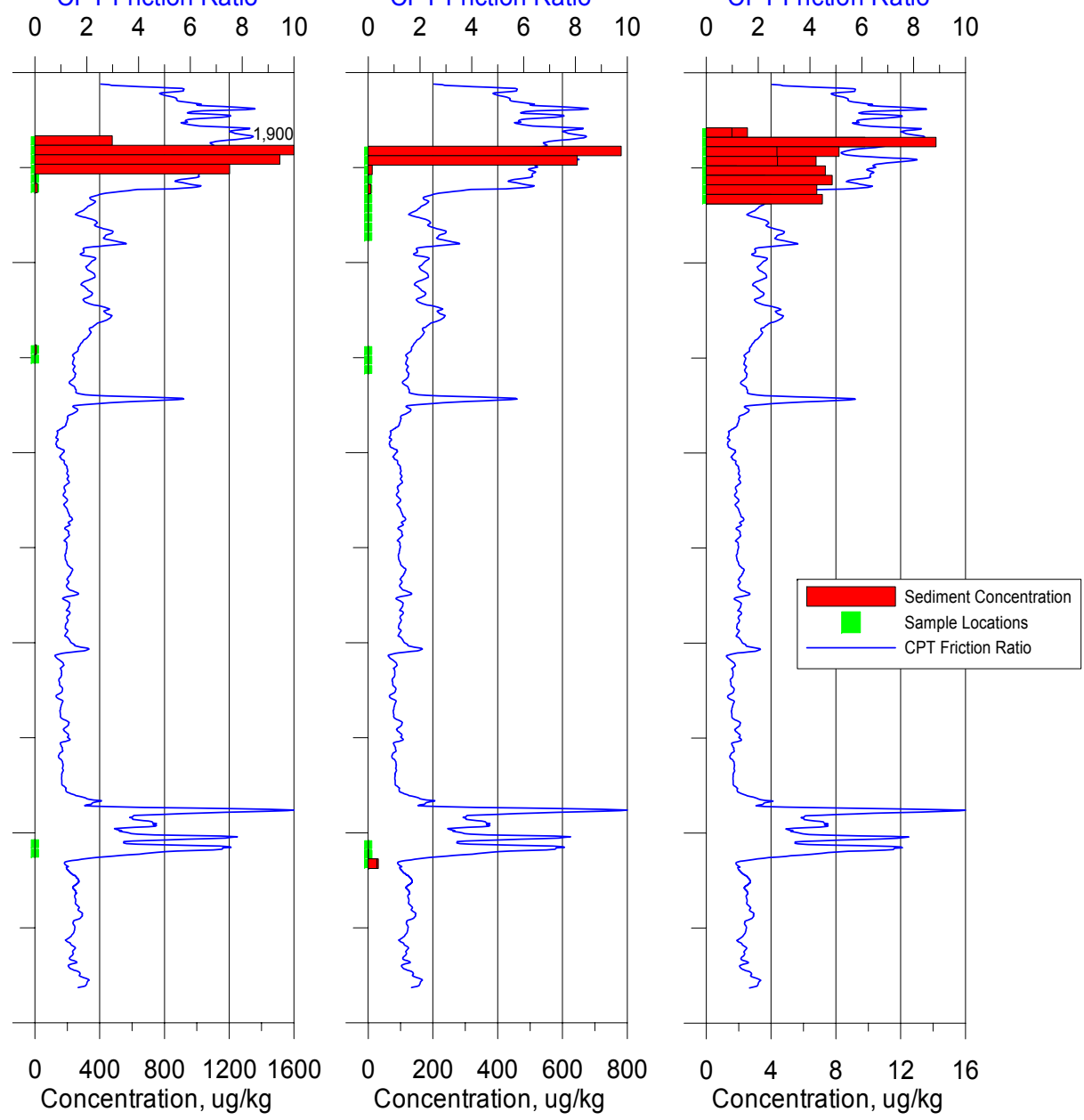

Figure 12 - PCE Temporal Sediment Concentration at Location 2 
WSRC-TR-2005-00266

MCB Mass Transfer Testing [Page 28]
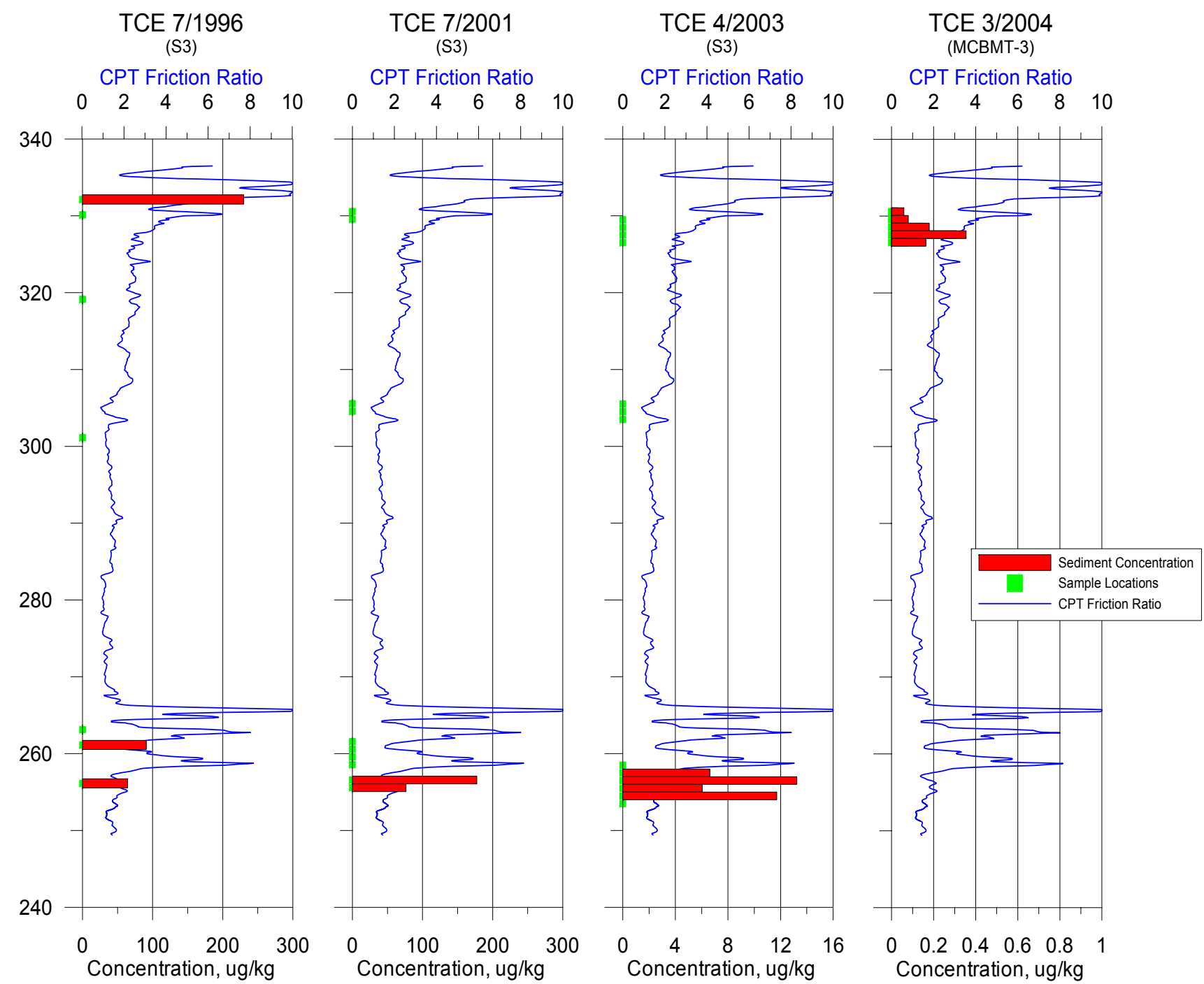

Figure 13 - TCE Temporal Sediment Concentration at Location 3 
WSRC-TR-2005-00266

MCB Mass Transfer Testing [Page 29]
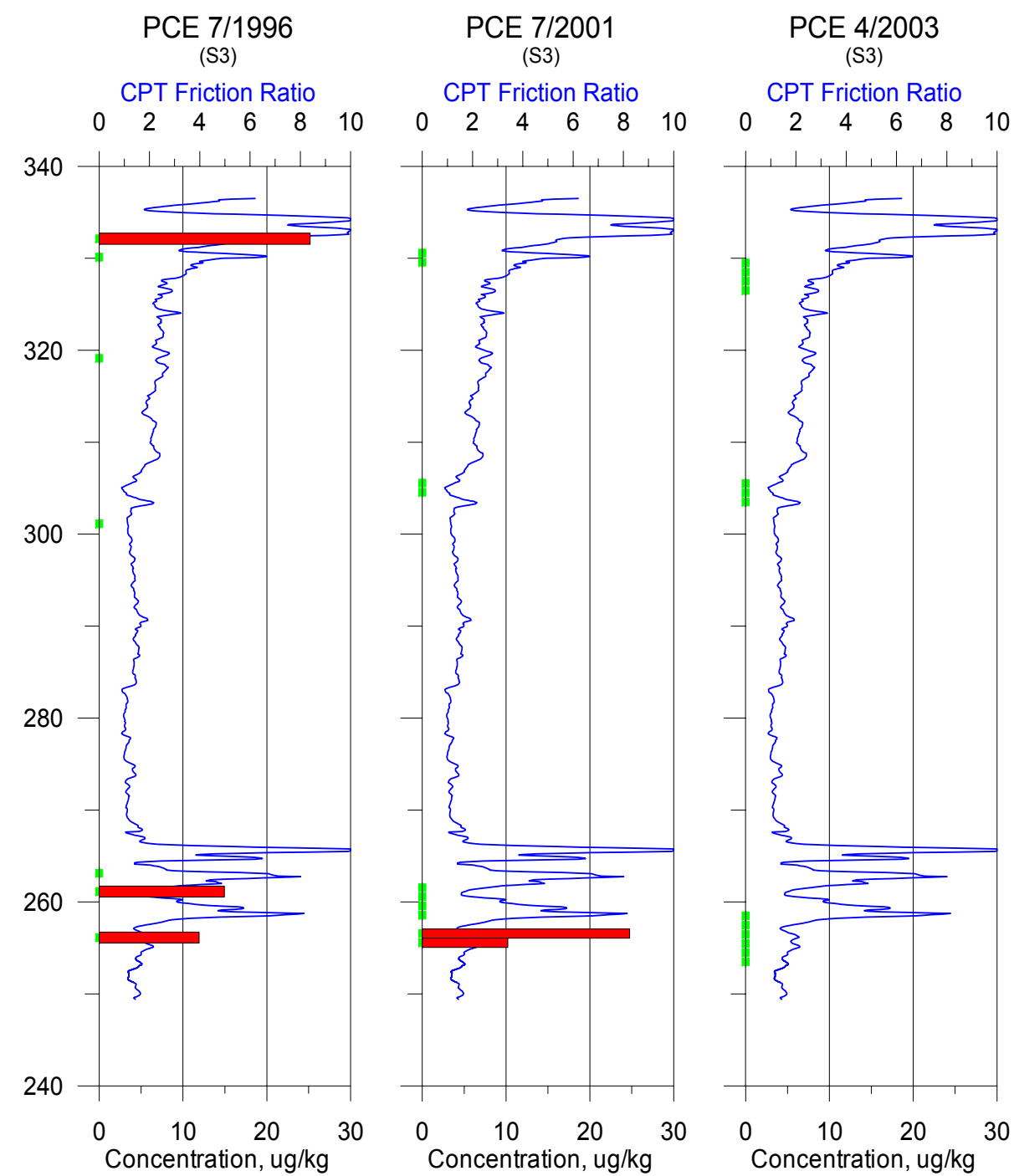
PCE 3/2004
(MCBMT-3)
CPT Friction Ratio

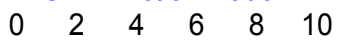

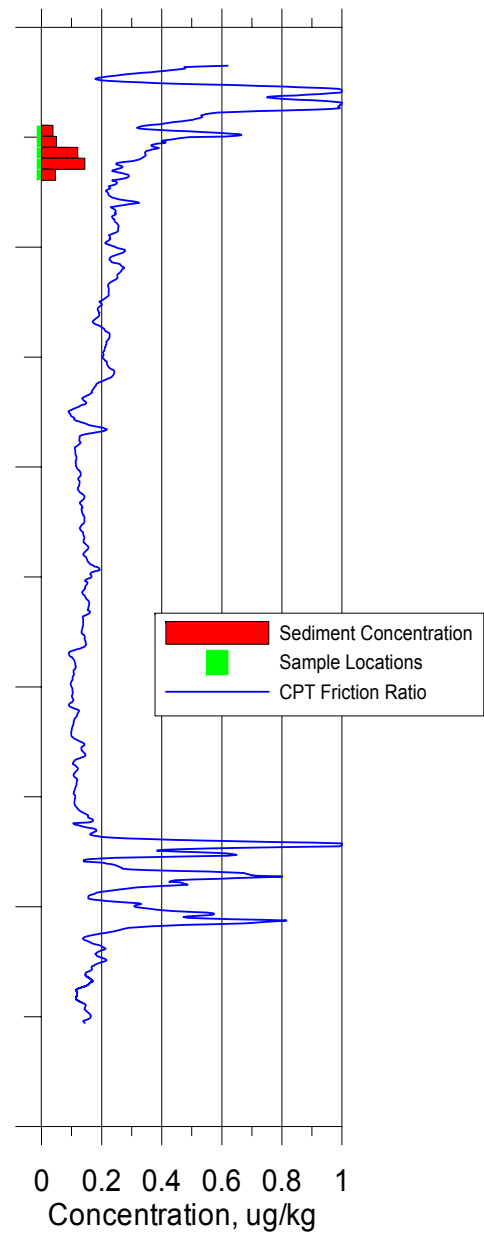

Figure 14 - PCE Temporal Sediment Concentration at Location 3 
WSRC-TR-2005-00266

MCB Mass Transfer Testing [Page 30]

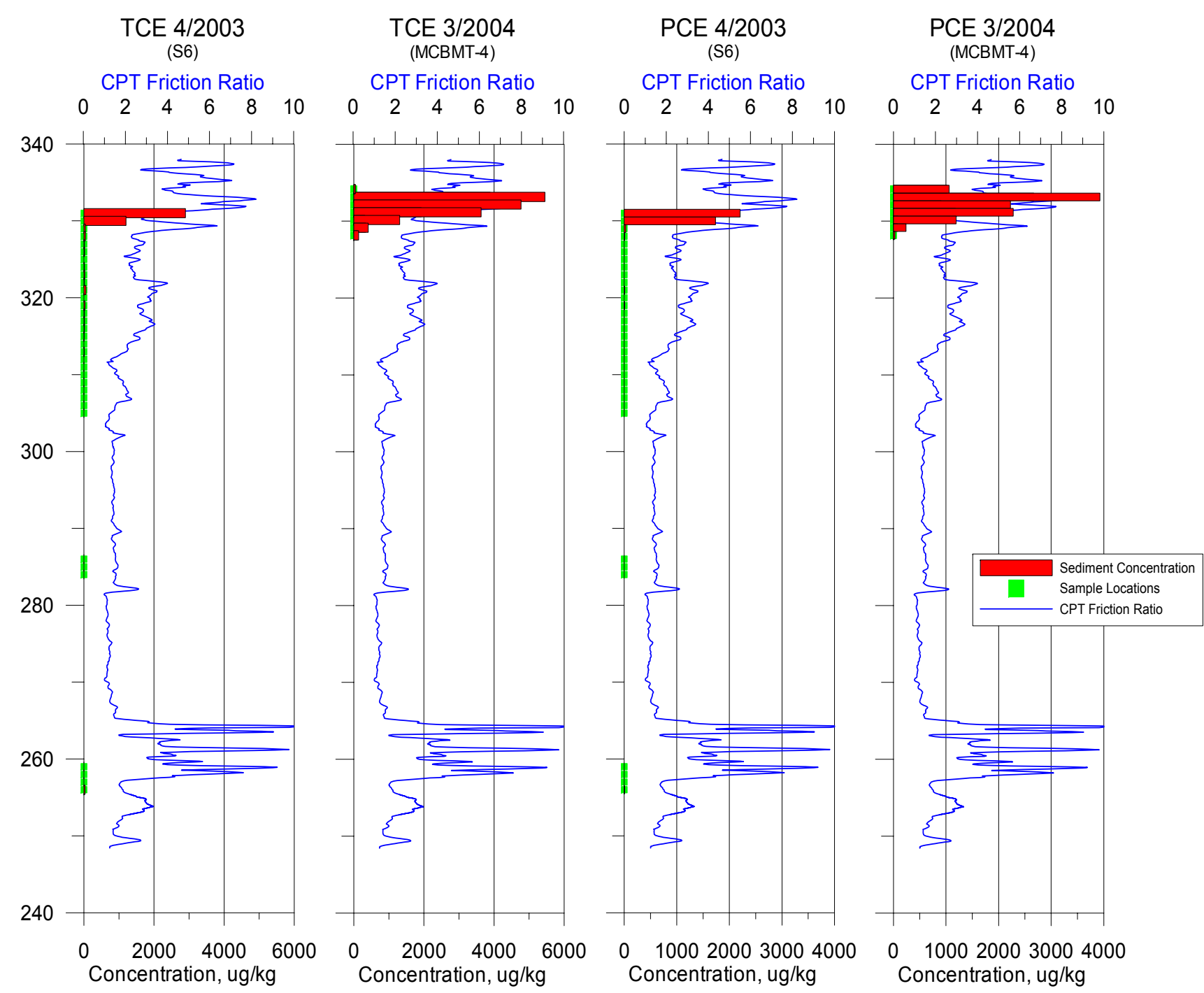

Figure 15 - PCE and TCE Temporal Sediment Concentration at Location 6 
WSRC-TR-2005-00266

MCB Mass Transfer Testing [Page 31]

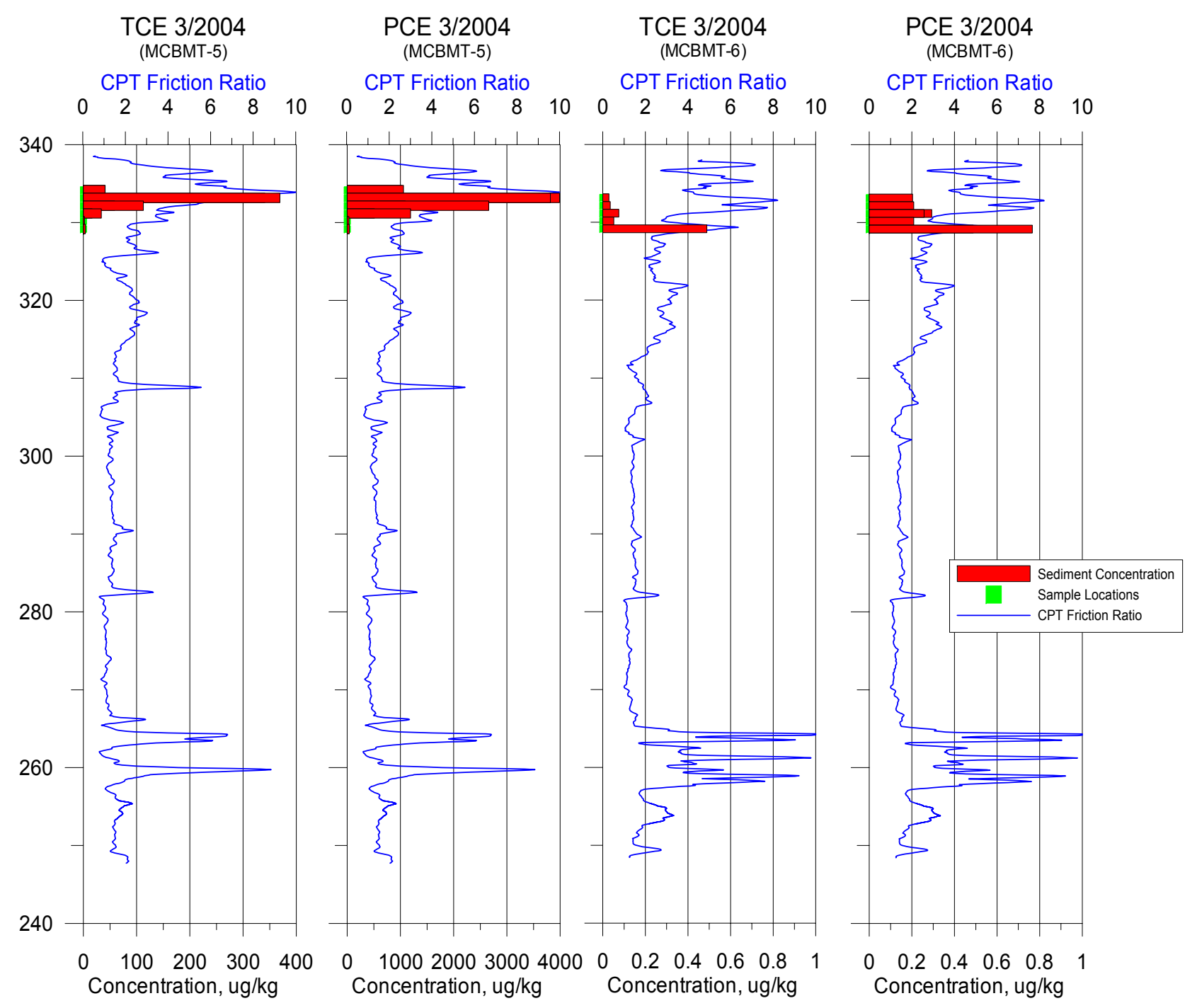

Figure 16 - TCE and PCE Sediment Concentration at MCBMT 5 and 6 
WSRC-TR-2005-00266

MCB Mass Transfer Testing [Page 32]

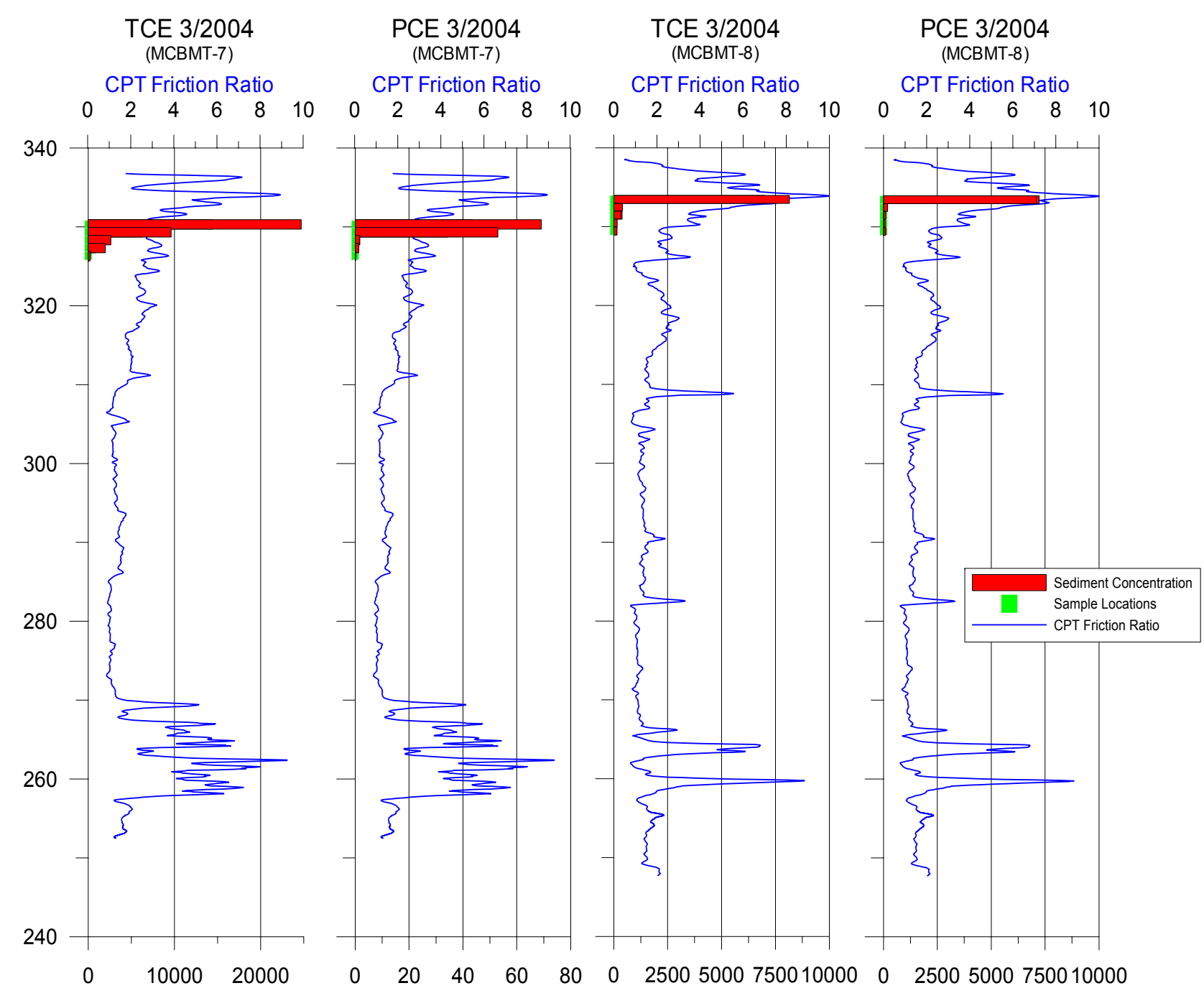

Figure 17 - TCE and PCE Sediment Concentration at MCBMT 7 and 8 
WSRC-TR-2005-00266

MCB Mass Transfer Testing [Page 33]

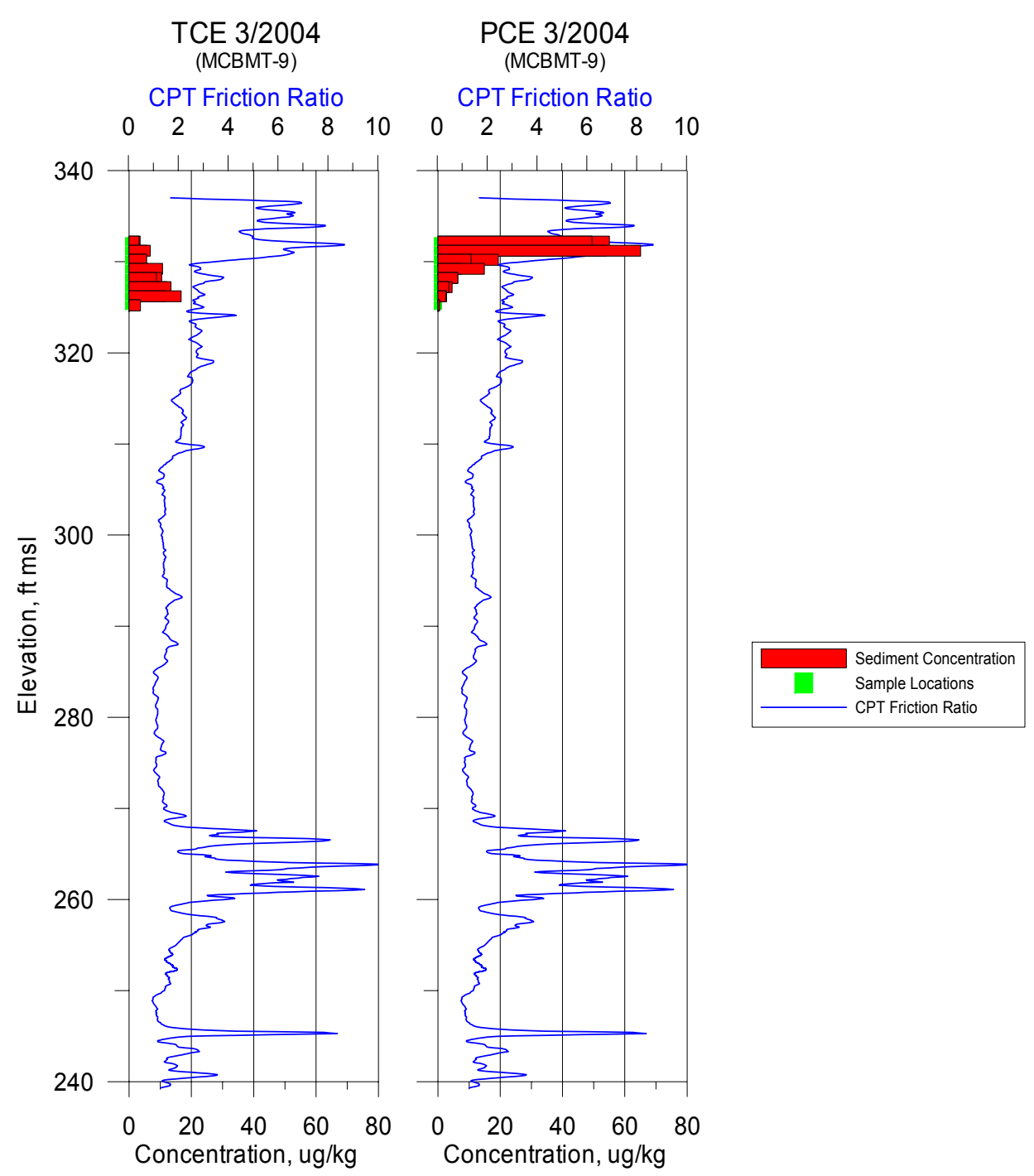

Figure 18 - TCE and PCE Sediment Concentration at MCBMT 9 


\section{Appendix B - Geophysical Parameters}

Six sediment samples were collected in the spring of 2003 and analyzed for moisture content, specific gravity, porosity, and capillary moisture relationships. Two samples were analyzed for grain size and four were analyzed for permeability. These samples were collected in brass tubes and sealed with plastic caps and tape and sent to Law Environmental Engineering and Environmental Services for testing.

The porosity values measured in the samples ranged from 0.33 to 0.40 and averaged 0.36 . Saturated hydraulic conductivity values in the samples tested were very low $\left(3.4 \times 10^{-7}\right.$ and $\left.6.6 \times 10^{-5} \mathrm{~cm} / \mathrm{s}\right)$ and are consistent with the silt and clay-rich sediments typical of the upland unit at the SRS. The water retention test results are also consistent with the high capillary forces in fine grain soils.

Table 9 - Laboratory Measured Geophysical Parameters

\begin{tabular}{|r|r|r|r|r|r|r|r|}
\hline Sample ID & \multicolumn{1}{|c|}{ Depth } & $\begin{array}{r}\text { Moisture } \\
\text { Content \% }\end{array}$ & $\begin{array}{c}\text { Wet } \\
\text { Density, pcf }\end{array}$ & $\begin{array}{c}\text { Dry } \\
\text { Density, pcf }\end{array}$ & $\begin{array}{c}\text { Specific } \\
\text { Gravity }\end{array}$ & Porosity & $\begin{array}{c}\text { Saturated } \\
\text { K, cm/s }\end{array}$ \\
\hline MCB-S2-1 & $8-8.5$ & 15.2 & 129.5 & 112.4 & 2.682 & 0.33 & $7.40 \mathrm{E}-07$ \\
\hline MCB-S2-2 & $18.5-19$ & 13.4 & 108.2 & 95.4 & 2.516 & 0.39 & $4.50 \mathrm{E}-06$ \\
\hline MCB-S2-3 & $19-19.5$ & 11.5 & 122.5 & 109.9 & 2.628 & 0.33 & \\
\hline MCB-S3-1 & $7-7.5$ & 19.2 & 119.9 & 100.6 & 2.640 & 0.39 & $6.60 \mathrm{E}-05$ \\
\hline MCB-S3-2 & $7.5-8$ & 19.2 & 119.2 & 100.0 & 2.681 & 0.40 & \\
\hline MCB-S3-3 & $8-8.5$ & 18.7 & 127.9 & 107.7 & 2.576 & 0.33 & $3.40 \mathrm{E}-07$ \\
\hline
\end{tabular}

Table 10 - Soil Classification Data

\begin{tabular}{|c|c|c|c|c|}
\hline Sample ID & Depth & \% Sand & \% Silt & \% Clay \\
\hline MCB-S2-1 & $8-8.5$ & 66.1 & 8.6 & 25.3 \\
\hline MCB-S2-2 & $18.5-19$ & 70.6 & 13.2 & 16.2 \\
\hline
\end{tabular}

Table 11 - Water Retention Test Data

\begin{tabular}{|l|l|l|l|l|l|l|l|l|l|}
\cline { 3 - 8 } \multicolumn{2}{c|}{} & \multicolumn{7}{c|}{ Applied Pressure, bars } \\
\cline { 3 - 9 } \multicolumn{2}{c|}{} & 0.0 & 0.05 & 0.1 & \multicolumn{7}{c|}{0.3} & 0.5 & 1.0 & 5.0 \\
\hline Sample ID & Depth, ft & \multicolumn{6}{|c|}{ Retained Water, \% by volume } \\
\hline MCB-S2-1 & $8-8.5$ & 32.7 & 27.8 & 27.6 & 27.3 & 27.3 & 26.5 & 23.3 \\
\hline MCB-S2-2 & $18.5-19$ & 37.5 & 17.9 & 17.8 & 15.1 & 14.0 & 12.8 & 10.0 \\
\hline MCB-S2-3 & $19-19.5$ & 30.7 & 20.9 & 20.8 & 19.2 & 18.6 & 17.9 & 14.5 \\
\hline MCB-S3-1 & $7-7.5$ & 38.8 & & 30.0 & 29.1 & 28.9 & 28.6 & 25.5 \\
\hline MCB-S3-2 & $7.5-8$ & 38.7 & 31.2 & 31.0 & 30.3 & 30.2 & 29.8 & 27.6 \\
\hline MCB-S3-3 & $8-8.5$ & 39.1 & 22.9 & 22.8 & 21.9 & 21.6 & 21.3 & 18.9 \\
\hline
\end{tabular}


Fifty-four samples were collected while targeting the fine grain zones for VOC sampling and were analyzed for water content by ASTM method D2216. The analysis was conducted at SRNL with very short sample hold times. This method provides a water content measurement by weight. The volumetric water content was calculated based on an average measured soil specific gravity of 2.62 and average porosity of 0.36 using the following relationships:

$$
V_{t}=V_{\text {soil }}+V_{w}+V_{\text {air }} .
$$

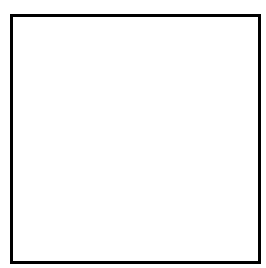

Where $V_{t}$ is the total soil volume, $V_{\text {soil }}$ is the volume of the soil particles and equals the dry soil weight times the specific gravity, $V_{w}$ is the volume of water and $V_{\text {air }}$. is the volume of air. The volumetric water content ranged from $10.9 \%$ to $56.2 \%$ with an average of $23.2 \%$. Using these same relationships, the air filled porosity $\left(\theta_{\mathrm{a}}\right)$ is $V_{\text {air }} / V_{t}$. $\theta_{\mathrm{a}}$ ranged from 0.00 to 0.28 with an average of 0.17 . 


\section{Appendix C - Integration Results for Total Mass Flux}

VOLUME COMPUTATIONS (Integration of contour grid of $J_{d}$ for TCE using Golden Software's Surfer ${ }^{\circledR}$ version 7.02)

UPPER SURFACE

Grid File:

X:IbdrIRIhadatalMass Transfer Tests|TCE lb ft2 yr.grd

Grid size as read:

Delta X:

81 cols by 100 rows

Delta Y:

1.052375

X-Range:

1.05414141414

Y-Range:

44819.64 to 44903.83

Z-Range:

97290.07 to 97394.43

$-1.81357450875 E-005$ to 0.00208031957397

LOWER SURFACE

Level Surface defined by $Z=0$

VOLUMES

Approximated Volume by

Trapezoidal Rule:

2.89361674055

Simpson's Rule:

2.89364792655

Simpson's 3/8 Rule:

2.89363775528

CUT \& FILL VOLUMES

Positive Volume [Cut]: $\underline{\mathbf{2 . 8 9 4 6 3 2 7 0 7 6 9} \mathrm{lb} / \mathrm{yr}}$

Negative Volume [Fill]: $\quad \mathbf{0 . 0 0 0 8 8 9 8 8 5 3 9 6 6 3 6}$

Cut minus Fill:

2.89374282229

AREAS

Positive Planar Area

(Upper above Lower)

Negative Planar Area

(Lower above Upper):

Blanked Planar Area:

Total Planar Area:

8669.83606982

116.232330182

0

$\underline{8786.0684 \mathrm{ft}^{2}}$

Positive Surface Area (Upper above Lower):

8669.83607248

Negative Surface Area

(Lower above Upper):

116.232330183 
VOLUME COMPUTATIONS (Integration of contour grid of $J_{d}$ for PCE using Golden Software's Surfer ${ }^{\circledR}$ version 7.02)

UPPER SURFACE

Grid File:

Grid size as read:

X:IbdrIRIhadatalMass Transfer TestsIPCE lb ft2 yr.grd

Delta X:

81 cols by 100 rows

Delta Y:

1.052375

X-Range:

1.05414141414

Y-Range:

44819.64 to 44903.83

Z-Range:

97290.07 to 97394.43

$-2.4178208229 \mathrm{E}-005$ to 0.000378420471111

LOWER SURFACE

Level Surface defined by $Z=0$

VOLUMES

Approximated Volume by

Trapezoidal Rule:

Simpson's Rule:

0.945474614983

Simpson's 3/8 Rule:

556257661

0.945553158176

CUT \& FILL VOLUMES

Positive Volume [Cut]: $\quad \underline{0.956402298023 ~ l b / y r}$

Negative Volume [Fill]: $\quad \mathbf{0 . 0 1 0 9 1 5 9 5 7 6 2 4 6}$

Cut minus Fill:

0.945486340399

AREAS

Positive Planar Area

(Upper above Lower)

Negative Planar Area

(Lower above Upper):

Blanked Planar Area:

Total Planar Area:

7717.00014545

1069.06825454

0

$\underline{8786.0684 \mathrm{ft}^{2}}$

Positive Surface Area (Upper above Lower): Negative Surface Area

7717.0001456

(Lower above Upper):

1069.06825454 